University of Wollongong

Research Online

Faculty of Informatics - Papers (Archive)

Faculty of Engineering and Information

Sciences

2009

\title{
A contingency model for creating value from RFID supply chain network projects in logistics and manufacturing environments
}

\author{
S. F. Wamba \\ University of Wollongong, samuel.fosso.wamba@neoma-bs.fr
}

A. T. Chatfield

University of Wollongong, akemi@uow.edu.au

Follow this and additional works at: https://ro.uow.edu.au/infopapers

Part of the Physical Sciences and Mathematics Commons

\section{Recommended Citation}

Wamba, S. F. and Chatfield, A. T.: A contingency model for creating value from RFID supply chain network projects in logistics and manufacturing environments 2009.

https://ro.uow.edu.au/infopapers/840

Research Online is the open access institutional repository for the University of Wollongong. For further information contact the UOW Library: research-pubs@uow.edu.au 


\title{
A contingency model for creating value from RFID supply chain network projects in logistics and manufacturing environments
}

\begin{abstract}
In the growing literature on RFID and other network technologies, the importance of organizational transformation at the supply chain level has been recognized. However, the literature lacks conceptual model development and salient mechanisms for achieving the level of organizational transformation required for stakeholders to realize the full business benefits from RFID projects. Furthermore, the RFID adoption, use, and impact studies to date largely focus on a single firm setting and on the retail sector. Therefore, this study intends to fill this knowledge gap in the literature, and develop a contingency model for creating value from RFID supply chain projects in logistics and manufacturing environments. For our model development, we draw upon extant diverse literatures; particularly the framework for IT-enabled business transformation (Venkatraman, 1994), and leadership and organizational learning. The framework postulates a positive relationship between the level of organizational transformation effected by the use of information technology (IT) and the level of business benefits realized from IT. The contingency model draws on the framework and explicates five contingency factors influencing value creation from RFID supply chain projects: environmental upheaval; leadership; second-order organizational learning; resources commitment; and organizational transformation. Using the contingency model as a conceptual guide, we also perform an analysis of longitudinal real-world case data from a Canadian third-party logistics service firm's seven-layer supply chain RFID projects. The case study analysis provides evidence for the imperative of the contingency factors identified in the model for creating value from the RFID projects. Furthermore, it also reveals the differential costs for the focal firm and the up-stream manufacturing as a key barrier to realizing the full RFID benefits at the supply chain level.
\end{abstract}

\section{Keywords}

RFID project, supply chain management, contingency model, benefits realization, integration, logistics, manufacturing

\section{Disciplines}

Physical Sciences and Mathematics

\section{Publication Details}

European Journal of Information Systems 18 (6): 615-636. 


\section{A Contingency Model for Creating Value from RFID Supply Chain Projects in Logistics and Manufacturing Environments}

Citation: Fosso Wamba, S. \& Chatfield, A. (2009). A contingency model for creating value from RFID supply chain network projects in logistics and manufacturing environments. European Journal of Information Systems 18(6): 615-636.

\begin{abstract}
In the growing literature on RFID and other network technologies, the importance of organizational transformation at the supply chain level has been recognized. However, the literature lacks conceptual model development and salient mechanisms for achieving the level of organizational transformation required for stakeholders to realize the full business benefits from RFID projects. Furthermore, the RFID adoption, use, and impact studies to date largely focus on a single firm setting and on the retail sector. Therefore, this study intends to fill this knowledge gap in the literature, and develop a contingency model for creating value from RFID supply chain projects in logistics and manufacturing environments. For our model development, we draw upon extant diverse literatures; particularly the framework for IT-enabled business transformation (Venkatraman, 1994), and leadership and organizational learning. The framework postulates a positive relationship between the level of organizational transformation effected by the use of information technology (IT) and the level of business benefits realized from IT. The contingency model draws on the framework and explicates five contingency factors influencing value creation from RFID supply chain projects: environmental upheaval; leadership; second-order organizational learning; resources commitment; and organizational transformation. Using the contingency model as a conceptual guide, we also perform an analysis of longitudinal real-world case data from a Canadian third-party logistics service firm's seven-layer supply chain RFID projects. The case study analysis provides evidence for the imperative of the contingency factors identified in the model for creating value from the RFID projects. Furthermore, it also reveals the differential costs for the focal firm and the up-stream manufacturing as a key barrier to realizing the full RFID benefits at the supply chain level.
\end{abstract}

Keywords: RFID project, supply chain management, contingency model, benefits realization, integration, logistics, manufacturing, value creation from RFID projects.

\section{Introduction}

The hypothesis for this study is that the potential operational and strategic benefits of radio frequency identification (RFID) technology would greatly increase when it is adopted and used beyond the traditional firm boundaries, and when it becomes seamlessly integrated both technologically and organizationally across the firm's supply chain. This is because when it is adopted and used effectively by a critical mass of stakeholders in the supply chain network, it impacts positive network externalities (or network effects) on supply chain logistics optimization, inter-firm information sharing, and inter-firm knowledge and technology transfer. 
Evidence supporting this hypothesis exists in prior research on the IT-enabled business and network transformation for business value (Venkatraman, 1994; Teo \& Pian 2003), on the electronic data interchange-enabled buyer-supplier operational and strategic benefits realization at the network level (Chatfield \& BjørnAndersen, 1997; Chatfield \& Yetton, 2000; Lai et al., 2008), as well as on the collaborative advantage through extended enterprise supplier networks at Toyota and Chrysler (Dyer, 2000). However, these diverse literatures also show the imperative of organizational transformation beyond the traditional firm boundaries, and the challenge for such a large-scale radical change.

Against this background, the RFID literature shows that while some technological feasibility and maturity has been demonstrated through proof-of-concept projects, the adoption, use, and impact of RFID studies have been limited to a single focal firm adoption setting (Stroh \& Ringbeck, 2004; Garcia et al., 2007), and largely in a retailing sector (Hardgrave et al., 2005; Fosso Wamba et al., 2006; Loebbecke \& Huyskens, 2008; Moon \& Ngai, 2008). In their review of academic literature on RFID, Ngai et al. (2008a) found that the highest frequency of peer-reviewed papers on RFID technology was concerned with the retail sector. Furthermore, little has been written about RFID knowledge and technology transfer within the supply chain network to generate network-wide operational and strategic benefits in real-time manufacturing and logistics environments. However, evidence shows that mere automation or electronic integration through RFID without business transformation is not sufficient to deliver improved logistics services (Lai et al., 2008). Therefore, this research is an initial effort towards bridging the existing knowledge gap in the literature. More specifically, this research draws on prior studies on RFID research agendas (Curtin et al., 2007, p. 97, 102) to examine the following three questions:

1. What is the economic value of RFID integration with (1) other applications (2) inventory, and (3) logistics?

2 . What role does the senior management, individual champions or agents of change play in the promotion of RFID?

3. How will the business value of RFID technology implementations be mediated by other organizational capabilities that drive value conversion?

In order to address these questions, this research draws on extant literature to develop a contingency model for creating value from RFID supply chain projects. More specifically, we draw both from the extant conceptual framework: "IT-enabled business transformation: from automation to business scope redefinition" (Venkatraman, 1994) and leadership and organizational learning literature (Newman, 2000; Schein, 2004; Kotter, 2007; Kotter \& Schlesinger, 2008). Using this initial contingency model as our guide, we then perform a longitudinal real-world case analysis of a third-party logistics (TPL) service provider and its supply chains. With in-depth insights gained from the case study research, we have refined the contingency model with respect to differential RFID investment costs among different stakeholders.

The remainder of this paper is structured as follows: Section 2 identifies contingency factors for RFID benefits realization from a literature review of the diffusion of innovation theory; RFID technology adoption in supply chain management; the Venkatraman (1994) framework, and leadership and organizational learning. Section 3 presents the (initial) contingency model for creating value from RFID supply chain projects. Section 4 describes our research methodology. Section 5 discusses a longitudinal case study of a Canadian TPL focal firm and its supply chains. Section 6 presents the discussion and Section 7 is our conclusion.

\section{Contingency factors for RFID benefits realization: a literature review}

\section{Diffusion of innovation theory}

Research on IT innovation is known to be multidisciplinary in nature, as it integrates different approaches and theories to examine why firms innovate, explore technological and organizational facilitators and barriers to innovation, and identify the methods used to promote innovation (Fichman, 2000). Most IT innovation studies, as Fichman notes, can be classified into two research streams: adopter studies and diffusion modeling studies. Both research streams have identified a number of factors affecting the diffusion and assimilation of IT innovations; namely, innovation characteristics, organizational characteristics and environmental characteristics (Rogers, 1995; Fichman, 2000; Tornatzky \& Fleischer, 1982; Zhu et al., 2006). Rogers (1995) postulates that five innovation characteristics may explain the decision to adopt an innovation: "relative advantage" as the degree to which an innovation can bring benefits to an organization; "compatibility" as the degree to which an innovation is consistent with existing business processes, practices and value systems; "complexity" as the degree to which an innovation is difficult to use; "observability" as the degree to which the results of an innovation are visible to others; and "trialability" as the degree to which an innovation may be experimented with. If we view RFID technology as a technological innovation, its characteristics such as no need of line of sight, multiple tags items reading, more data storage capability and improved asset visibility are thought to influence adoption decision.

With regard to organizational characteristics, early studies on innovation diffusion established a strong relationship between the firm's IT adoption and organizational characteristics, such as organizational readiness, which is defined as the level of technical and financial resources available in the firm (Lee \& Shim, 2007); organizational size, which is measured by organizational slack resources, organizational structure and decision-making flexibility (Zhu et al., 2006); organizational culture with a focus on centralization vs. decentralization, and management support (Zhu et al., 2006; Fichman, 2000; Iacovou et al., 1995). Finally, a range of environmental characteristics has been identified that can influence the firm's decision to adopt an innovation, including the intensity of competitive pressure (Zhu et al., 2006; Teo et al., 2003; Fichman, 2000), the standard and regulation (Kraemer et al., 2006), and the nature of business relationship (e.g., stakeholders pressure, position in the business network, and trust) (Zhu et al., 2006; Iacovou et al., 1995).

The innovation diffusion literature reflects the different information technologies studied and at the different unit of analysis used in prior research, for example, at the individual level adoption, the business unit level, and the firm level. However, prior research in general has not focused upon network technology innovation diffusion at the supply chain level. 


\section{RFID innovation adoption in supply chain management}

The concept of supply chain management (SCM) is defined as "the integration of key business processes from end user through original suppliers that provides products, services and information that add value for customers and other stakeholders" (Lambert \& Cooper, 2000, p. 66). This definition suggests that a seamless integration of the key business processes across the supply chain is required to achieve operational optimization at the supply chain level. However, the concept of SCM also has strategic value implications. For example, SCM is often viewed as "the $21 \mathrm{st}$ century global operations strategy for achieving organizational competitiveness" (Gunasekaran \& Ngai, 2004, p. 269). Increasingly, its strategic importance is generally accepted in the academic community (Ragatz et al., 1997; Frohlich \& Westbrook, 2001).

\section{RFID technology}

In the past, a vast range of information technologies has been used by supply chain stakeholders to achieve supply chain optimization and manage buyer-supplier relationships. More recently however, RFID technology, a wireless automatic identification and data capture (AIDC) technology, has been emerging as the new wave of inter-organizational systems (IOS) that is expected to transform the interdependent supply chain business processes and the supply chain management practices (Srivastava, 2004; Bose \& Pal, 2005; Lefebvre et al., 2006; Curtin et al., 2007; Bose \& Lam, 2008; Fosso Wamba et al., 2008; Lee \& Park, 2008; Sabbaghi \& Vaidyanathan, 2008).

The concept behind RFID technology is not that complex, consisting of an RFID tag that contains an antenna and a chip with rewritable information about the tagged item or product. When this RFID tag enters a RFID reader's reading area, a bidirectional communication is established between the tag and the reader through radio frequencies. The reader retrieves and sends the unique product identification to a RFID middleware, where business logics are configured for further processing. The RFID reader can be either 'fixed' or 'mobile' with having a read or read/write capability (Ngai et al., 2007). It can be configured to control the timing communication with the RFID tag (the reader talks first) or to react to messages from the tags (the tag talks first) (Asif \& Mandviwalla, 2005).

\section{RFID benefits}

When compared to bar-coding - traditional AIDC technologies, RFID technology offers a greater range of advantages: a unique item/product level identification, no need of line of sight, multiple tags items reading, more data storage capability and data $\mathrm{read} / \mathrm{write}$ capabilities (Asif \& Mandviwalla, 2005). However, RFID is considered as a disruptive innovation (Lefebvre et al., 2006; Vail \& Agarwal, 2007), since it is thought to radically change interdependent supply chain processes and practices (Fosso Wamba et al., 2006; Bardaki et al., 2007; Curtin et al., 2007; Whitaker et al., 2007; Chuang \& Shaw, 2008).

For example, when successfully integrated into supply chain business processes, RFID technology improves inventory record inaccuracies (Heese, 2007), enhances organizational coordination and control (Cannon et al., 2008), enables real-time data collection and sharing among the supply chain stakeholders (Bose \& Pal, 2005; Fosso Wamba \& Boeck, 2008), offers new technological capabilities for product information storage and tracking (Legner \& Schemm, 2008), enables supply chain business process innovation (Fosso Wamba et al., 2006, Loebbecke \& Palmer, 2006; Fosso Wamba et al., 2008), and improves supply chain efficiency and effectiveness (Bose \& Pal, 2005; Michael \& McCathie, 2005; Loebbecke, 2007; Loebbecke \& Huyskens, 2008; Moon \& Ngai, 2008). All these benefits, if realized, would enable the supply chain to provide new products and services (Loebbecke \& Palmer, 2006; Leimeister et al., 2009), which would give rise to competitive advantage at the firm level (Leimeister et al., 2009).

\section{RFID challenges}

Despite the potential benefits from RFID technology, especially in the supply chain context, the current adoption rate is still fairly low, between $7 \%$ and 15\% (Schmitt \& Michahelles, 2009), mainly due to the unresolved key issues associated with its network externality. The organizational issues in creating value from RFID supply chain network projects include the integration of RFID systems with existing intra- and inter-organizational information systems and business processes; training for all the personnel involved (Jones et al., 2004; Hingley et al., 2007; Goswami et al., 2008); the scope of RFID-enabled supply chain projects (White et al., 2008; Bensel et al., 2008) and that of change management (Hingley et al., 2007); technical 'know-how', available resources, and level of automation (Bensel et al., 2008); the absence of project champions (Lee \& Shim, 2007); top management support (Ngai \& Gunasekaran, 2009; Brown \& Russel, 2007; Seymour et al., 2007); high implementation costs (Hingley et al., 2007; Ngai \& Gunasekaran, 2009); and the significant gap between RFID implementation costs and the realized benefits for each of the supply chain stakeholders (Bensel et al., 2008).

Importantly, Sharma et al. (2007) concluded that top management commitment at the firm and inter-organizational levels is required for the coordination and business process reengineering of an RFID-enabled supply chain. They underscored that: a "long term strategic vision and direction from top management is critical to RFID adoption and integration in and between firms" (p. 7). Also, Karkkainen \& Holmstrom (2002) highlighted the importance of integrating RFID technology with IOS to achieve end-to-end supply chain visibility. In the same line of thought, Fosso Wamba et al. (2008) and Bendavid et al. (2009) underscore the importance of seamless integration of RFID technology with intra-and inter-organizational processes and systems to reduce inefficiencies in the supply chain, and facilitate more collaborative practices.

Furthermore, Bendoly et al. (2007), Bovenschulte et al. (2007), and Lai et al. (2006) all concluded that the full benefits realization of RFID-enabled supply chain projects depends on knowledge transfer and knowledge sharing across early adopters of RFID technology and late adopters, and those who are still exploring and evaluating the potential benefits of technology for them. These studies strongly suggest that (1) it is necessary to set frameworks, guidelines, tools, and mechanisms to help define - in a better way - the scope of the RFID supply chain project and the level of organization transformation and (2) it is necessary to identify the realistic benefits and costs at the supply chain level as well as at the firm level. 


\section{Existing RFID implementation frameworks}

Recent interest in RFID technology has generated an increasing number of implementation frameworks for assessing the level of implementation in SCM (Fontanella, 2004; Chuang \& Shaw, 2007; Sabbaghi \& Vaidyanathan, 2007). However, none of these frameworks fully address the two requirements we have discussed earlier in the previous section. For example, Fontanella (2004) distinguishes four phases of RFID implementation: 1) the application of RFID technology to a discrete process to reduce the shortcomings of the extant technology (e.g., bar code) or manual process; 2) the use of RFID technology as an enabler of intraorganization optimization across two or more entities (e.g. business units) within a firm. Here, the focus is largely technological, not organizational. The complexity, risks and benefits associated with RFID implementation are higher than in the previous case. However, to fully realize the potential of the technology, "additional steps must be taken to ensure that the operating environments conform to the technology's requirements. This includes the distance between the readers and the product, the elimination of potential interferences from other automation equipment, and the protection of the tag from weather conditions or damage" (p. 13-14); 3), the application of RFID technology at the inter-firm level as a means to synchronize and coordinate processes with a limited number of supply chain stakeholders to offer differentiated services; and 4) the synchronization, which refers to the ubiquitous use of RFID technology across an entire industry to achieve and sustain a global vision of supply chain efficiency and effectiveness, through the use of common standards among a critical mass of RFID adopters.

Similarly, Chuang \& Shaw (2007) suggest a three-stage RFID integration model to assess the scope of RFID implementation. In the first stage, "functional RFID integration", organizations mainly used the technology for a single process or a single internal activity (e.g. distribution center processes, JIT manufacturing processes, or asset tracking activity). The second stage, "business unit RFID integration", involves the extension of RFID integration to different business units within an organization (e.g. headquarters, manufacturing, warehouses, or distribution centers). Here, the "implementation requires a scalable RFID architecture designed to meet a portfolio of expectations. Team skills and more complex business cases are used to achieve synergy in the supply chain" (p. 85). Finally, the third stage, "inter-company RFID integration", evaluates the collaboration between a focal firm and its supply chain partners to implement RFID technology at the supply chain network level. It is argued that this level of integration is complex, and has a high degree of technical and business risks and requires the development of a mutually beneficial strategy for all supply chain stakeholders.

In the same vein, Sabbaghi \& Vaidyanathan (2007) use the five levels of SCM evolution that deal with internal integration to test the current position of RFID implementation within firms through a field survey (Poirier, 2002; Sabbaghi \& Vaidyanathan, 2007). By focusing on three functional applications, namely, (1) the sales and customer service, (2) logistics, transportation, and warehousing, and (3) inventory and materials management, they found that for each of these functional applications, various industrial managers in the US are currently using the RFID technology at the five different levels of SCM evolution. Moreover, the managers in the study believed that at the full network connectivity stage (level 5), the RFID technology "can be used in all three functions equally" (p. 445). Finally, all firms under study were exploring the potential of RFID technology in their SCM efforts.

A review of the RFID implementation frameworks strongly implies a positive relationship between the level of electronic integration through RFID implementation and RFID benefits. Therefore, our first proposition is:

Proposition 1: The higher the level of electronic integration through RFID implementation is, the higher the RFID benefits.

However, a review of the RFID implementation frameworks show that they do not address the two requirements discussed earlier and that conceptual model development would be useful to facilitate the stakeholders of RFID projects - both the focal firm and its supplier chain firms - to create value from their RFID project investments. We therefore, review the existing framework for IT-enabled business transformation (Venkatraman, 1994) in the next section.

\section{Venkatraman framework}

Much has been written in the IOS literature on business value creation for networked organizations through IT-enabled business process redesign (Venkatraman, 1994; Chatfield \& BjørnAndersen, 1997; Chatfield \& Yetton, 2000; Grover \& Saeed, 2007). For example, Venkatraman (1994) proposed a conceptual framework for IT-enabled business transformation, which is relevant for us to understand the role of organizational transformation in realizing the potential RFID benefits, and hence creating business value from RFID supply chain projects. His framework was based on the premise that the level of the potential IT benefits that can be realized by a given organization is directly related to the degree of organizational transformation affected by the use of IT. Venkatraman identified five different levels of business transformation (Figure 1): localized exploitation, internal integration, business process redesign, business network redesign and business scope redefinition.

As shown in Figure 1, Venkatraman considered the first two lower levels of business transformation as "evolutionary", because the primary focus at these lower levels is to create operational efficiency gains within a focal firm through electronic integration. He states clearly that no radical organizational change is involved: "Even if the redesign efforts extend outside the focal organizational boundary, no attempt is made to shift the scope of the business from within the firm to outside and vice versa (except for streamlining administrative efficiency) (p. 85)." In this sense, the first two lower levels of business transformation are similar in nature to incremental change (Dunphy \& Stance, 1988; Orlikowski, 1993), first-order organizational learning (Newman, 2000; Lant \& Mezias, 1992; Schein, 2004); single-loop learning (Argyris, 1991), and continuous improvement (Hall, 1987; Adler et al., 1999) in just-in-time manufacturing and within the Toyota Production System.

In contrast, the next three higher levels represent the "revolutionary" levels of business transformation that are designed to enhance organizational capabilities at the focal firm level as well as at the network level. On the one hand, the third level, "Business Process Redesign", still confines organizational transformation within the focal firm boundary. On the other hand, at the next two higher levels - "Business Network Redesign" and "Business Scope Redefinition", organizational transformation 
efforts extend beyond the traditional firm boundaries into transforming network stakeholder organizations for the higher level benefits realization from the use of IT.

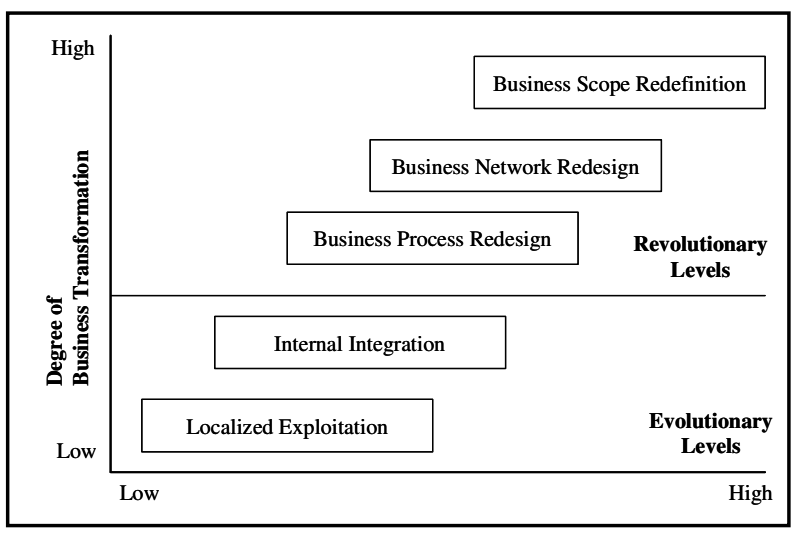

Figure 1 Venkatraman (1994) conceptual framework

However, at these two higher network levels, the transformation of interdependent inter-firm business processes and inter-firm transaction relationships is significantly more complex and more costly, with respect to the level of managerial and organizational resources required to make radical changes or effect a fundamental shift in the established business processes and procedures between the firms. An important managerial challenge is to balance the tradeoffs between benefits and costs at the individual firm level, as it was stated that "each organization should first identify the transformational level where the benefits are in line with the potential costs (efforts) of the needed organizational changes (p. 73)."

By distinguishing the "revolutionary" levels of inter-firm transformation from the "evolutionary" levels of firm transformation, Venkatraman argues that the potential costs required for achieving a greater degree of organizational transformation are different and certainly higher. Although it does not specify any mechanisms for reducing such costs and achieving organizational transformation at the network levels, the framework addresses the costs involved in transforming the networked organizations and achieving the potential benefits at the network levels. Importantly, Tushman \& Anderson (1986) demonstrated that technological discontinuities or breakthroughs had historically produced either positive (enhancing) or negative (destructive) impacts on the existing organizational competence, which therefore decreased or increased environmental turbulence and uncertainty. Therefore, it is important to identify key contingency factors that would have positive or negative impacts of RFID technology on creating value from RFID supply chain projects. In fact, with regard to the impacts of RFID technology on many suppliers, particularly the SMEs, they are not entirely positive (Spekman \& Sweeney II, 2006; Bardaki et al., 2007). Therefore, our second set of propositions is:

Proposition 2: RFID-enabled organizational transformation has a direct impact on benefits realization from RFID projects.

Proposition 2a: The wider the scope of organizational transformation, the higher RFID benefits.

\section{Leadership and organizational learning}

The leadership and organizational learning literature shows the importance of executive leadership for guiding and steering the process of organizational transformation, allocating and committing resources, and supporting second-order organizational learning (Newman, 2000; Schein, 2004; Kotter, 2007; Kotter \& Schlesinger, 2008). As we noted earlier, the literature lacks the clear identification of useful mechanisms for moving RFID project stakeholders from lower to higher levels of benefits realization. Therefore, in this section we review the leadership and organizational literature to distinguish second-order organizational learning from more familiar first-order organizational learning.

\section{First-order and second-order organizational learning}

The literature recognizes that organizational transformation initiatives often experience resistance to change that impedes the realization of firm level business benefits from the initiatives importantly, this barrier exists even within the firm boundary of a single organization (Kotter, 2007; Kotter \& Schlesinger, 2008). In contrast to the literature on the IT-enabled business transformation (e.g., Venkatraman (1994), the leadership and organizational learning literature on organizational transformation does not explicitly consider IT as playing a central role in explaining organizational transformation.

Organizational transformation involves the destruction of the long-established organizational and institutional routines, and making a fundamental shift away from the institutionalized patterns of beliefs, attitudes and behaviors (Van de Ven \& Poole, 1995; Newman, 2000) in order to initiate "a new order of things" (Kotter \& Schlesinger 2008, p. 130). Therefore, the literature shows the importance of developing strategic change leadership skills to create a new change-friendly culture (Schein, 2004), and lead a powerful buy-in that guides the coalition of leaders (Kotter, 2007). According to John Kotter and Leonard Schlesinger (2008), resistance to change is why organizational transformation is very often avoided by managers and staff; but it is also due to other reasons, including parochial self-interest, misunderstanding and lack of trust in the change initiator, different assessments of the same situation, and individual low tolerance for change. It is obvious that transforming the whole or part of the supply chain network is increasingly complex as compared to the transformation of the intra-firm business processes of a single organization.

The increasing complexity in leading and managing larger scale organizational transformation initiatives suggests that strategic leadership is imperative in leading organizational transformation (Kotter \& Schlesinger, 2008; Schein, 2004) and that second-order organizational learning (Lant \& mezias, 1992; Newman, 2000) and double-loop learning (Argyris \& Schon, 1978; Argyris, 1991) play the central role in reducing organizational barriers and getting people actively engaged in organizational transformation. In her Academy of Management Review paper on organizational transformation, Newman (2000) proposed a new theoretical framework that draws upon organizational change theory, institutional theory, and organizational learning theory. The effect of institutional upheaval on a causal chain of organizational activities that lead to organizational transformation was examined. According to the 
framework, institutional upheaval originates in radical change in the institutions of society, such as "political systems, laws, regulations, financial markets, and underlying assumptions about the purpose of economic activity" (p. 602). Her study focused on organizational transformation during "a period of intense social, political, and economic change" (p. 602): the fall of communism in Central and Eastern Europe. However, her theoretical framework is highly relevant to this paper's objectives, because as we discussed earlier in this paper, RFID technology is often considered as disruptive, and its adoption is often mandated by the focal firm. This means that while it may open the doors to innovations and new business opportunities for the focal (buyer) firm, it will likely cause an institutional upheaval to many suppliers who are pressured to comply with the adoption mandate.

Newman argues that the impact of institutional upheaval on second-order learning varies according to the level of intensity of the upheaval. While first-order learning is associated with the mastery of established organizational routines to effect incremental change or continuous improvement, second-order learning often occurs in response to an upheaval in a competitive environment, or a subsequent internal crisis. While first-order learning is an adaptation of established routines, second-order learning is a fundamental shift away from the established routines; searching for new routines when existing routines become ineffective, or when they cannot explain a new or emerging phenomenon. Newman (2000) found that a certain level of institution-level upheaval promotes and facilitates organizational transformation, because it enables second-order organizational learning. However, she postulates that an extreme level of institutional upheaval inhibits organizational transformation, because it also inhibits second-order organizational learning. An analysis of the leadership and organizational literature leads us to the following four propositions.

Proposition 3: Effective leadership has a positive impact on organizational transformation.

Proposition 4: Second-order organizational learning has a positive impact on organizational transformation.

Proposition 5a: Environmental upheaval up to a point has a positive impact on second-order organizational learning.

Proposition 5b: Excessive environmental upheaval beyond organizational (financial, technological, or managerial) capabilities has a negative impact on second-order organizational learning.

\section{A contingency model for creating value from RFID supply chain projects}

In the previous section, the review of the relevant literature, including the current RFID research agendas (Curtin et al., 2007; Ngai et al., 2008a) has enabled the identification of five salient contingency factors for our model for creating value from RFID supply chain projects. They are: environmental upheaval, leadership, second-order organizational learning, resources commitment, and organizational transformation at the supply chain level. Figure 2 below shows this contingency model for creating value from RFID supply chain projects. The model shows that these five contingency factors directly or indirectly influence our dependent variable, the level of RFID benefits realization, and hence value creation from RFID supply chain projects. The model makes three underlying assumptions.
First, we recognize both the focal firm and supplier firms as key stakeholders in a supply chain electronic integration project through the adoption and use of RFID technology. This is because network externalities and inter-firm business process interdependence means that the level of RFID benefits realized by the focal firm from its RFID supply chain project is influenced by the level and scope of RFID technology adoption and use by its suppliers.

Second, we assume that organizational transformation, in the present context of creating value from RFID supply chain projects, must necessarily include increased level of RFIDenabled electronic integration. This is based on the central premise of the Venkatraman framework (1994). Finally, the model underscores the imperative of organizational transformation at the supply network level for higher level benefits realization, because as the literature shows consistently that a mere automation or electronic linkage within the focal firm or even at the inter-firm level is not sufficient to realize the full potential benefits of RFID technology. Furthermore, the model underscores the imperative of organizational transformation at the supply network level for higher level benefits realization, because the literature shows consistently that a mere automation or electronic linkage within the focal firm, or even at the inter-firm level, is not sufficient to realize the full potential benefits of RFID technology. Importantly, we argue that the same contingency factors such as environmental upheaval and resources commitment may exert differential effects in the model depending on different stakeholders, for example, the focal firm or a supplier. This is because these contingency factors dynamically interact with the leadership factor. In this section, we explain our contingency model.

\section{Environmental upheaval}

Environmental upheaval in this RFID research context may include change in the business environment and the resulting new business pressures the focal firm may face or new RFID mandates the supplier has received from a customer. The literature shows a positive impact of environmental upheaval on the organization up to a certain point - on triggering and enabling second-order learning (Newman, 2000). However, if the impact overwhelms the organization's internal resources such as leadership capacity and financial capacity, then it inhibits organizational learning, particularly second-order organizational learning. In the context of RFID supply chain projects, the RFID literature shows that organizational readiness (Lee \& Shim, 2007; Bensel et al., 2008), such as financial resources, matters for RFID benefits realization and that this may be a more acute issue for suppliers rather than the focal firm that often initiates a RFID supply chain project.

\section{Leadership}

We postulate that presence or absence of effective strategic change leadership influences the level of organizational transformation achieved at the focal firm level as well as at its supply chain level. As a response to the environmental upheaval, the organization undertakes an organizational transformation initiative - in our paper - RFID-enabled supply chain transformation. Whether the upheaval is a customer mandated RFID project or a RFID pilot project for new business value creation, it involves organizational transformation, which is 
different, in scale and scope, from continuous improvement or evolutionary change. In consequence, effective strategic change management strategy and strategic communication of changeoriented initiatives play a central role in managing the organizational resistance to change as well as in creating a new organizational culture that supports and sustains the radical change.

Therefore, effective strategic leadership at the senior management level, at the firm level, becomes imperative for each stakeholder organization to realize higher level RFID benefits from a given RFID project. However, this contingency factor becomes even more critical, at the network level, to promote the wider adoption and use of RFID technology across the entire supply chain. The management literature reviewed in the previous section has shown the importance of the focal firm leadership to form a coalition of change leadership which includes the senior management of the key supplier firms (Argyris \& Schon, 1978; Argyris, 1991; Van de Ven \& Poole, 1995; Newman, 2000; Schein, 2004; Kotter, 2007; Kotter \& Schlesinger, 2008) and prior to research on RFID adoption (Ngai \& Gunasekaran, 2009; Bendoly et al., 2007, Bovenschulte et al., 2007; Lai et al., 2006).

\section{Second-order organizational learning}

Based on the management literature, we postulate in our contingency model that the environmental upheaval, up to a certain level, exerts a positive effect on the organization's secondorder organizational learning. In this paper, we discuss the second-order organizational learning capabilities in the context of organizational transformation, and include the organizational capability for inter-firm knowledge and technology transfer that is considered to have positive impacts on the level of RFID benefits realization (Bendoly et al., 2007, Bovenschulte et al., 2007; Lai et al., 2006). We argue that organizational transformation at the firm, inter-firm, or network level, requires effective second-order organizational learning capabilities, which include the focal firm's capability to facilitate knowledge and technology transfer to suppliers - particularly SMEs - which possess less organizational and technological resources.

\section{Organizational transformation}

Consistent with the organizational transformation literature mainly the Venkatraman (1994) framework and prior studies on RFID adoption (Jones et al., 2004; Hingley et al., 2007; Sharma et al., 2007; Goswami et al., 2008; Bensel et al., 2008) - the model shows that RFID technology must be seamlessly integrated with the web-based applications and internal information systems both within the focal firm and the supplier firm. Furthermore, this electronic integration needs to be matched by organizational transformation in respect to the organizational integration of business processes within the firm, and between the focal firm and the supplier. Finally, the model shows that the level of organizational transformation also has differential effects on the level of RFID benefits realization (Sharma et al., 2007; Bensel et al., 2008).

Like Venkatraman (1994), we also assert that electronic integration without organizational transformation, such as business process redesign at the firm level, and at the supply chain network level, would yield limited returns on IT investments. As a result, the contingency model underscores how imperative the organizational transformation is to realize higher-level RFID benefits from RFID supply chain projects.

\section{Resources commitment}

In the current context of RFID supply chain projects, the literature often shows that the focal firm has a commitment to a given RFID pilot or implementation project, while its suppliers vary in the level of organizational readiness. Here in the model, we have used the term 'resources commitment' to underscore the importance of financial resources required for the adoption of RFID technology and non-financial resources such as project teams. In the model, this contingency factor is influenced by the presence or absence of effective strategic leadership, as the IT project management literature shows the importance of top leadership support and executive project championship (Englund $\&$ Bucero, 2006). On the one hand, with the presence of effective strategic leadership and resultant sufficient resources commitment, higher level of organizational transformation and higher level of RFID benefits realization can be facilitated. On the other hand, the absence of such leadership and the lack of commitment of financial and non-financial resources to the RFID project, this contingency factor is thought to have a negative, inhibitory effect on organizational transformation, and hence inhibiting higher level of RFID benefits realization at the focal firm and at the supply chain level.

\section{Dependent variable}

In this model, the ultimate dependent variable of interest is value creation from RFID supply chain projects. However, we consider RFID benefits realization as an intermediate step towards creating economic and strategic value from the projects.

The postulated relationships between the contingency factors and RFID benefits realization are shown in Figure 2 below.

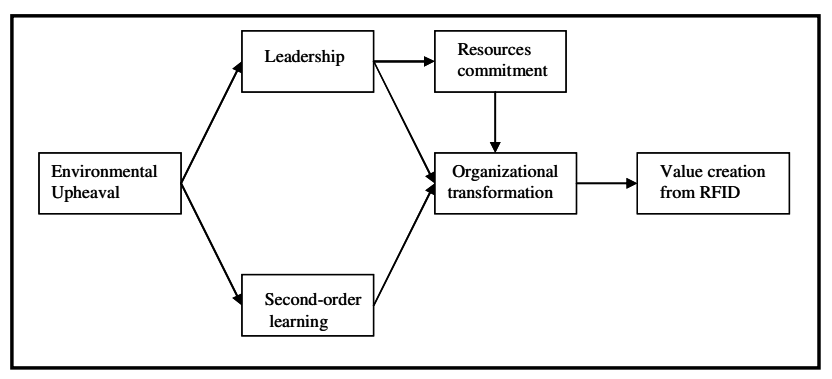

Figure 2 Contingency factors influencing RFID benefits realization

In summary, we draw on the conceptual model of IT-enabled business transformation (Venkatraman 1994), to assume in our contingency model that the level of RFID benefits is positively associated with the level of organizational transformation in the focal RFID project champion organization. Successful organizational transformation through RFID technology - even if it is a TPL firm or a buyer such as Wal-Mart - requires changeoriented second-order organizational learning and effective change leadership. Furthermore, the focal firm needs to facilitate second-order organizational learning at the supply chain level to promote RFID technological knowledge and technology transfer 
to the key stakeholders of the enterprise supply chains. Ultimately, our contingency model postulates that the realization of the full potential benefits from a RFID technology project at the supply chain level would require that all stakeholders of the project radically transform the entire supply chain network. Not only do the RFID project stakeholders need to work collaboratively towards inter-organizational efficiency gains, but also they have to improve the quality of inter-organizational relationships such as mutual trust, shared problem solving capabilities, and information sharing. However, it should be noted that our contingency model differs from that of

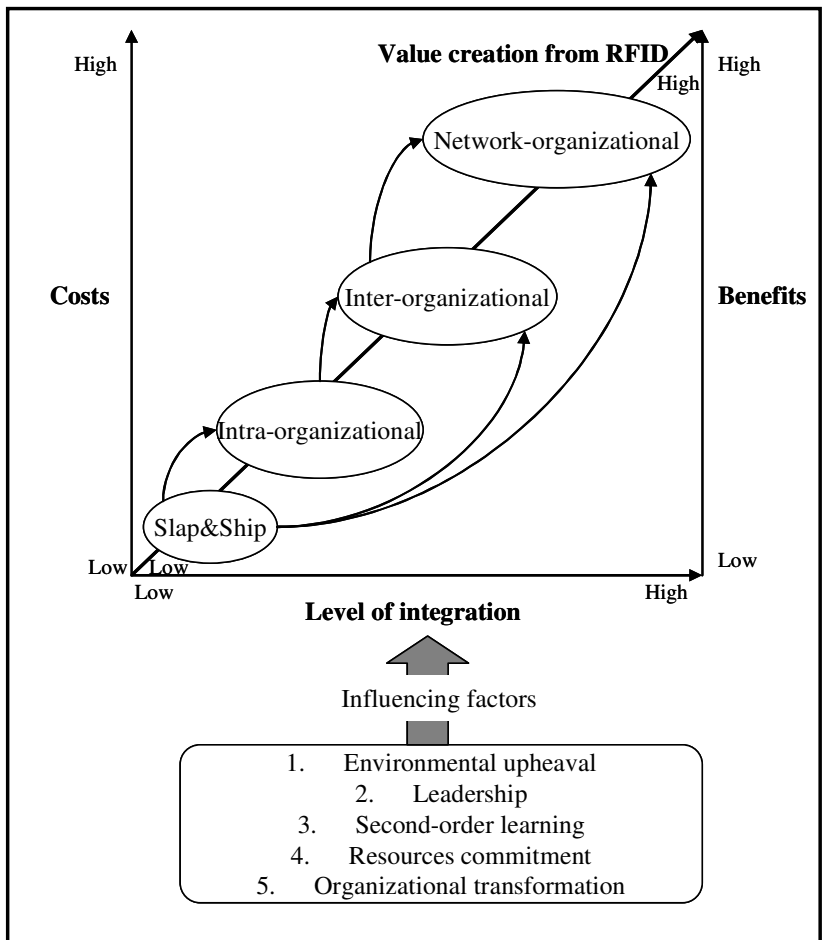

Figure 3 Contingency model implications for effective RFID integration across a supply chain

Venkatraman (1994) in two important ways:

(1) We explain how the commitment, or the lack thereof, of financial resources influences the level of organizational transformation, which will be discussed more detail later in this paper. In our discussion, we have explicitly identified the costs associated to the level of electronic integration and organizational integration in order to manage the RFID project successfully for benefits realization and value creation.

(2) We have identified second-order organizational learning as a necessary mechanism for the stakeholders to move from one level of RFID benefits to the next higher level.

As discussed earlier in the paper, the contingency model for creating value from RFID supply chain projects shows that a causal chain of the five contingency factors influences the level of RFID benefits realized. Moreover, the costs associated with organizational transformation, which includes electronic integration and business process optimization; need to be recognized for effective project management.
The implications of our contingency model are shown in Figure 3 to highlight the interdependency among the main relationships - the level of integration, the scope of RFID project (i.e. the unit of analysis for organizational transformation), the costs and benefits. The model implications enable the identification of three critical success factors for a successful RFID project: (a) The level of integration, which encompasses technological and organizational integration; (b) The level of technological and organizational integration, which requires that the key stakeholders of the project design an intra-organizational and/or inter-organizational transformation; (c) The level of integration and the scope of organizational transformation, which, if attained, may have different impacts on the costs and benefits of the RFID project.

Figure 3 identifies four distinct RFID project milestones: Slap \& ship; Intra-organizational integration; Inter-organizational integration (among some high value stakeholders); and supply chain network integration (across all stakeholders). In the following section, we will describe each project milestone with respect to the key benefits that the organization can realize from the scope of RFID project, as well as the costs associated with the level of technical and organizational integration and the degree of organizational transformation that are required for the project to be a success at the milestone level.

\section{Slap \& Ship RFID projects}

A Slap \& Ship RFID project is motivated by the focal firm's mandate that is issued to the suppliers. Regardless of the size of supplier organizations, they often respond to the mandate with the only real option available for their business survival: compliance.

\section{Level of integration}

\section{Technological Integration}

The scope of this level of RFID project is very limited, since it is driven by the supplier organization's mere compliance to the mandate. Hence, RFID integration is extremely limited to providing the focal firm with an add-on RFID sticker on the product to be shipped. The supplier's investment is limited to the procurement of an RFID passive tag printer to print out RFID stickers. These RFID stickers can be read by the focal organization's RFID readers.

Organizational Integration \& Organizational Transformation The supplier organization creates an additional set of business processes and extra-staff that are required to comply with the RFID mandate. Very little or no organizational transformation is involved.

\section{Benefits}

There may be a potential business value for the focal firm in the sense of obtaining accurate information on the finished goods shipped in transition and received at the focal firm's warehouse. RFID-enabled automation may improve internal inventory control for the focal firm. However, there is virtually no operational optimization or business value creation for the supplier.

\section{Costs}

The main costs in the slap \& ship RFID projects are those associated with the creation of a supplier's additional set of business processes, the purchase of RFID tags and RFID printer, and the extra staff responsible for applying RFID tags on products. 


\section{RFID-enabled intra-organizational integration projects}

RFID-enabled intra-organizational integration project is driven by internal control, intra-organizational business process innovation and operational cost reduction.

\section{Level of integration}

Technological Integration

The technological integration involves the deployment of the different RFID components depending on the configuration being chosen (portal, smart shelf or conveyor), the design of business rules in the middleware to establish a bridge between the "virtual RFID infrastructure" and the "physical RFID infrastructure", and finally, the integration of the RFID infrastructure with the existing intra-organizational information systems (e.g. enterprise resource planning (ERP), warehouse management system (WMS) or database management system (DBMS)).

Organizational Integration \& Organizational Transformation

The level of organizational transformation depends very strongly on the level of business process transformation and on the size of the organization. Concerning radical business processes (e.g. the rise of a receiving process and put-away process and/or picking process with shipping process), the redesign of warehouse (e.g. elimination of staging area) shall be required.

\section{Benefits}

Whether it is from the focal firm or the supplier's perspective, RFID-enabled intra-organizational integration project is regarded as a means to achieve:

1. Internal control through the use of a new control mechanism at the financial level, that is, for instance, the real-time verification of shipments (e.g. receiving for focal firm and shipping for supplier), the proof of deliveries and receipts for billing purposes, and at the operational level, internal control over inventory in terms of real-time inventory in the warehouse, which renders the conduct of time- consuming activities such as annual counting unnecessary;

2. Internal process innovation in terms of cancellation, automation, redesign, integration and efficiency (e.g. receiving, put-away, picking, packing and shipping);

3. The operational cost reduction in labor for inventory management and control; and

4. The improvement of data collection, data accuracy, data integrity and data quality. In general, the optimization of intraorganizational operations is achieved by the supplier through the use of RFID; higher benefits for the adopting firm (supplier or focal firm) and some benefits for the rest of supply chain stakeholders.

\section{Costs}

They encompass the costs related to process standardization, the RFID infrastructure (tags, readers, middleware, and auxiliary devices such as photo eyes, camera, and motion sensor), the costs of the site survey, and the selection of RFID equipments, testing, deployment, monitoring, troubleshooting and maintenance, and the integration of RFID infrastructure with the existing IS. Also, we have associated costs such as human resource training, the cost of upgrading the existing mobile assets (e.g. moving from standard forklift to forklift integrating an RFID mobile reader).

\section{RFID-enabled inter-organizational and network organizational optimization projects}

The third and fourth levels of RFID supply chain projects aim at inter-organizational electronic integration through RFID technology. A simple example of these levels of electronic integration is a 'focal firm-supplier' dyad. Here the focal firm can be either a TPL service provider or a buyer such as Wal-Mart. The difference between these levels of electronic integration and the two other levels discussed earlier is that the new flow-on benefits from the RFID project involve suppliers when they integrate RFID with their internal information systems, and externally with their customers' internal IS, which enables them to support interorganizational business processes. Assuming the focal firm successfully manages its own RFID-internal IS integration, this tight electronic integration will enable up-stream suppliers to access to real-time RFID data on the tagged product movement, as well as to the inventory level of the focal firm. This new enhanced information flow enables better market demand forecasting and more accurate procurement and manufacturing planning. Here the flow-on benefits go to the suppliers who are willing to transform their internal business processes and to integrate RFID with their internal IS.

While there is evidence that the focal firm often exercises greater market power than its up-stream suppliers, and mandates them to adopt the RFID technology so as to optimize the existing inter-firm business processes, the focal firm's power is limited as it cannot force either the RFID-internal IS integration in, or the transformation of, the supplier organization. The supplier may have no other choice but to adopt the "Slap \& Ship" mandate compliance. However, it has strategic options with respect to the level of internal integration and automation as well as to the level of organizational transformation. Importantly, SME suppliers may resist to moving up to this level from at least one of the lower levels of integration because they do not have sufficient technological knowledge about RFID and/or organizational learning capabilities to realize higher level benefits.

In a supply chain network, there is an array of dyads (e.g. focal firm-supplier 1, focal firm-supplier 2, and so forth) at this level of electronic integration. This requires a wider scope for the RFID supply chain project, which makes it necessary to include not only the key stakeholders of the focal firm, but also those of supplier organizations, in order to have a successful RFID implementation. The active involvement of the suppliers in the project is required to maximize their return on investment (ROI) from new technology infrastructures and new organizational capability developments. However, the more the key stakeholders are involved, the more complex the management of the RFID supply chain project for the focal firm becomes. Managerial and organizational issues such as resistance to change, the lack of supplier knowledge, and the effective knowledge and technology transfer are emerging. The leadership failure to address them effectively and in a timely manner might lead to the failure to achieve the full potential benefits of RFID technology.

Furthermore, consistent with early studies on RFID technology which postulate positive impacts of project champions (Ngai \& Gunasekaran, 2009; Brown \& Russel, 2007; Lee \& Shim, 2007; Seymour et al., 2007) and technological knowledge (Lee \& Shim, 2007; Huber et al., 2007) on RFID adoption and usage, our contingency model postulates the importance of change leadership and the focal firm's capability to facilitate knowledge and 
technology transfer to the suppliers involved in the RFID project. Our contingency model addresses the issue beyond the adoption and explains how to move to the next level of higher RFID benefits. In addition, as in the case of the Internet, business transformation is a key factor leading to the RFID full potential realization (Teo \& Pian, 2003).

In addition to the costs of the RFID-enabled intraorganizational integration discussed earlier, the supply chain stakeholders need to incur additional costs related to the standardization of inter-organizational business processes, interorganizational IS interfaces, and the costs related to their implementation and the transaction costs of managing and monitoring the organizational change. Moreover, they need to take into consideration training costs of the inter-organizational process owner at the supply chain level, the switching costs to a unique RFID standard; for example, moving from a different inhouse RFID labelling to an electronic product code, generation II (EPC Gen 2).

In addition to these tangible costs that are easier to quantify, the up-stream suppliers are also expected to incur 'intangible' organizational costs, including:

-Organizational costs of building inter-firm trust, so that inter-firm information sharing can be automated without any human intervention. This raises the issues of how best to share the costs and how best to transfer the capabilities of supply chain stakeholders (SME vs. big enterprise) across the supply chain network.

\section{Research methodology}

The current project is conducted in the TPL industry and involves the study of activities related to the management of telecommunications stationary batteries of a TPL supply chain. This deliberate choice is in line with the recommendations of Prater et al. (2005 p. 134), who argue that the RFID-enabled supply chain study and discussion should be conducted within a specific business domain as the business impacts of the applicability of RFID technology will be influenced by its environment.

\section{Case study research for theory building}

The main objective of this study is to develop a deep theoretical understanding of the RFID-enabled supply chain for value creation. The study adopts a research design: the case study research for theory development (Eisenhardt, 1989), and is grounded in real-life settings. This RFID case study began in September 2007 with an informal meeting between the research team leader and the President of the TPL firm, which will be discussed later in Section 5. The President was exploring different strategies to expand its current "slap \& ship" RFID initiative. He wanted to extend the initiative to all activities related to the management of telecommunications batteries, which would enable his firm to provide new value added services and to use RFID technology as a strategic tool to promote a "green image" of its business. Thereafter, a longitudinal case study in a seven-layer TPL supply chain (Figure 5) was conducted over an eight-month period between September 2007 and April 2008, with a follow-up in March and April 2009 to examine RFID post-adoption behaviours and consequences (Robey et al., 2008) and a final interview with the President of the TLP.
This research strategy is suitable to address our research questions, since it enables researchers to capture the dynamic interactions within the supply chain (Eisenhardt, 1989), to focus on emerging and complex phenomena, and to induce theories (Benbasat et al., 1987). In addition, case studies are well suited to answer research questions such as "why" and "how" things are done (Yin, 1994), and are appropriate to study RFID-enabled supply chains for value creation in this paper, where research and theory are at their early and formative stages (Benbasat et al., 1987). Moreover, a longitudinal case study strategy allows observations and analyses of complex and interdependent processes that may change over time (Davidson, 2002). An increasing number of scholars promote the use of case study research in the logistics and operation management fields (Barrat, 2004; Näslund, 2002), and many research studies have already proved its validity and utility in the study of RFID technology (Fosso Wamba et al., 2006; Moon \& Ngai, 2008; Ngai et al., 2008b; Loebbecke \& Huyskens, 2008). The current longitudinal case study offers a unique perspective to analyze the RFIDenabled supply chain impacts in real-life settings.

\section{Data collection}

In this longitudinal case study, multiple sources of evidence were used, including interviews, on-site observations, focus groups, and living laboratory approaches, which allowed us to increase our construct validity (Yin, 1994). Our research cycle and the multiple data collection methods are shown in Figure 4.

Case study interviews were conducted with three different groups. The first group consisted of key informants across the supply chain from operational levels such as warehouse clerks and truck driver clerks and management levels such as the President of the focal firm, directors of operations, warehouses managers, and project managers. These informants were selected since RFID could have huge impacts at these two levels. The second group included the team from the RFID solution provider, such as the Director of Integration Services, Vice-President of Production and Services, and software developer engineers. Finally, the third group consisted of the team from "the RFID School" which included the President of the RFID School, Director of Administration, and the Director of Business Development. Each interview lasted approximately one and a half hours and allowed open-ended probing questions. All data gathered during these interviews were recorded in a database and reviewed both by the key informants from business and the RFID solution provider team.

In addition, multiple on-site observations were conducted in the supplier or customer organizations' research sites in order to analyze the current intra-organizational and inter-organizational business processes related to the telecommunication batteries management. This enabled the researchers to understand the supply chain dynamics and the business environment. Thereafter, all intra-organizational and inter-organizational business processes were mapped ("as-is") using a modeling and simulation tool called Aris Toolset, which were validated through several iterations with key supply chain stakeholders. For example, semistructured interviews with managers and operational personnel enabled us to gain more in depth information and solve any potential inaccuracy in the mapping of existing business processes. 
Afterwards, several RFID workshops were organized jointly by a team from the RFID School and a team from the RFID solution provider at the RFID School facilities to introduce the technology, including infrastructure, potential impacts on logistics processes, current operational limitations, and ROI calculation, to all stakeholders involved in the project. These knowledge transfer workshops enable all process owners to gain the necessary knowledge to discuss the business process redesign - integrating RFID across the supply chain network.

These RFID workshops were followed by three focus groups conducted at the focal firm facilities with key supply chain stakeholders and a research team of RFID experts. The focus groups facilitated the key RFID-enabled supply chain stakeholders to reach a consensus on the strategic intent in relation to the use of RFID as an enabler of telecommunications batteries management across the supply chain.

From the focus-groups, two most plausible scenarios of RFIDenabled supply chain (discussed later in Section 6) were being chosen and assessed in the RFID solution provider laboratory through the "Living Laboratory" approach. Here, the physical and technological environments, interfaces between all actors in the supply chain are simulated, followed by a discussion on the feasibility of RFID technology for each of the scenarios and their evaluation in terms of business process automation, ISintegration, and real-time data collection and sharing. In fact, the "Living Laboratory" approach was intended to support diverse research settings, including the simulation of business experiments and the use of the laboratory over a prolonged period by all key RFID project stakeholders for "self-trial" learning (Loeh, 2005), joint problem solving, interaction, knowledge generation and exchange among all key project stakeholders (Kusiak, 2007; Konsti-Laakso et al., 2008; Bergvall-Kåreborn et al., 2009). Finally, one scenario of RFID-enabled supply chain was selected (which may not be necessarily the optimal one) to be implemented and monitored during a pilot project.

During the whole process of this project, the research team played different roles, ranging from that of participants (e.g. when performing the modeling and simulation of several scenarios pertaining, to the RFID-enabled supply chain optimization using the modeling and simulation tool) to that of observers (e.g. when conducting on-site observation).

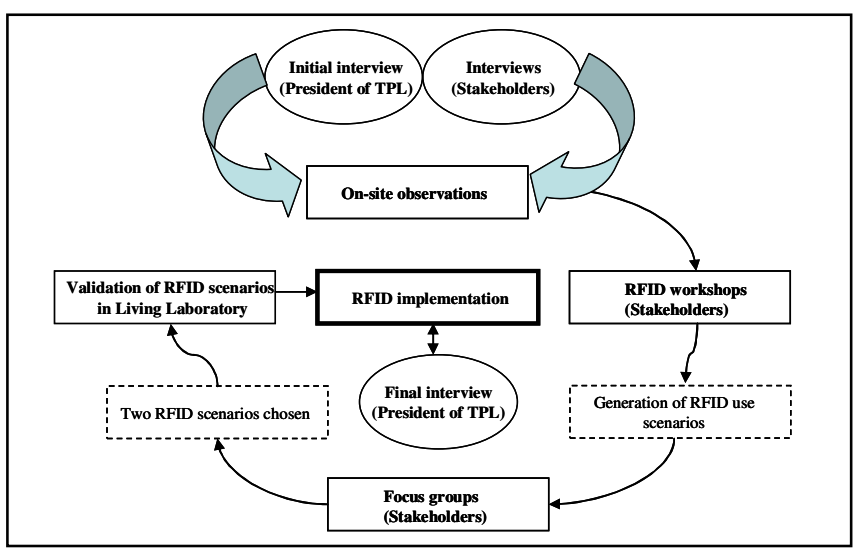

Figure 4 Research cycle and corresponding data collection methods

\section{A Canadian TPL supply chain network}

\section{TPL industry}

The rapid growth of third-party logistics (TPL) reflects the contemporary business environment which is characterized by market globalization, aggressive competition, growing cost pressures, a rise of customized demand and an increasing use of outsourcing. (Power et al., 2007). A TPL firm provides a bundle of logistics services to buyers and/or suppliers on a contractual basis (Razzaque \& Sheng, 1998). More specifically, a TPL is defined as "a relationship between a shipper and a third-party which, compared with the basic services, has more customized offerings, encompasses a broad number of service functions and is characterized by a long-term, more mutually beneficial relationship" (Murphy \& Poist, 1998, p. 35). A TPL firm usually conducts all or part of its customer's logistics activities, such as transportation, warehousing, and inventory management. As a result, it has become an integral part of many firms' supply chains for operational efficiency gains (ALPHA Research Consortium, 2004; Bayraktar et al., 2008; Marasco, 2008).

For example, a TPL firm enables its customers to focus on their core competencies and provides flexibility in the adaptation to the new technology, resource and workforce size (Bayraktar et al., 2008). In this sense, major TPL activities have become commoditized (van Hoek, 2000). In consequence, many TPL firms are under competitive pressure to innovate constantly in order to create value for their customers. One of the important avenues for value creation is an innovative use of IT, as the "technological effort becomes a critical variable and a significant tool for differentiation of logistics services" (Evangelista \& Sweeney, 2006, p. 56).

In their efforts to create value for their customers, a wide range of IT has been used by TPL firms to achieve supply chain optimization; for example, bar-coding, visibility tools, ERP, WMS, transport management system (TMS) and EDI. More recently, RFID technology has been emerging as a new enabler for creating value in supply chain management practices in general and in the logistics industry in particular. The logistics industry is a leading user of RFID technology. In fact, the adoption of RFID technology by TPL firms could be viewed as the "next logical step" in their IT portfolio.

\section{A Canadian seven-layer TPL supply chain}

The case study was conducted in a seven-layer TPL supply chain in Canada, and focused on logistics activities involved in managing telecommunications stationary batteries (Figure 5). The focal firm is a Canadian owned medium-size TPL service provider, with annual revenue of nearly US\$23 million and 52 full-time employees. It owns a large distribution center in Montreal, Canada and several warehouse facilities in the U.S. to provide a wide range of services, including storage, transport and customs clearance.

The Montreal distribution center is used to store telecommunications batteries shipped from various suppliers; all batteries manufacturers. Based on the market demand from its three major customers: a telecommunication company, a communication provider, and a utility company, the TPL firm transports new batteries to customers' various remote sites, collects used batteries upon demand, and transports them to 
recycling company facilities. Prior to any battery transportation to a remote site, the TPL firm provides customers with an additional service in corporate social responsibility (CSR) and government environmental regulatory compliance. It prepares 'a manifest' documentation on behalf of its customers. It contains all detailed technical, manufacturing, and engineering information requirements which are mandated by the Ministry of Environment of Quebec, such as the specifications of the batteries, the type of liquid in batteries, metal, glass, weight and other relevant details.
President (Figure 6), suppliers would implement RFID at their facility, which is then gradually extended to the rest of the supply chain stakeholders in order to increase the network externalities.

Moreover, the labeling of batteries with the RFID tag should be met in each supplier's facilities prior to their shipment to the focal firm warehouse. This implies two radical changes for the suppliers. First, the suppliers need to redesign their business processes. Second, their IT and physical infrastructures need to be redesigned with a view to integrating RFID technology.

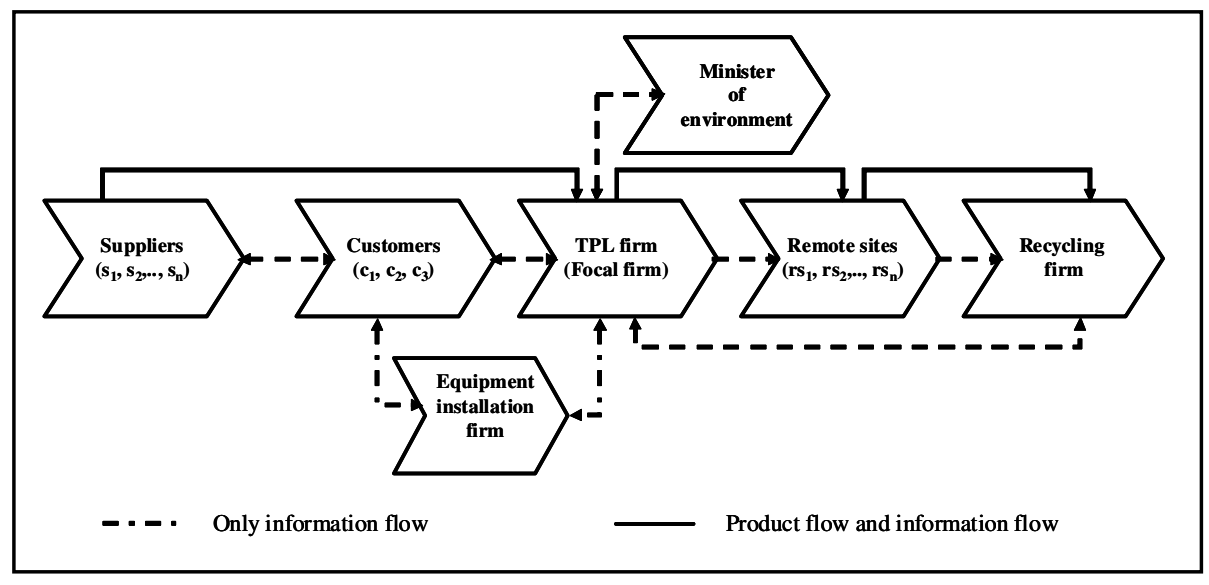

Figure 5 The TPL supply chain

In fact, the effective management of those batteries throughout their life cycle is critical, because they are considered by Quebec law as hazardous products, and hence they have special requirements for their transportation, disposal and recycling. For example, all major stakeholders in the supply chain involved in the management of batteries are required to be able to locate, monitor, and keep track of the accurate quantity of recycled components from the used batteries in a timely manner. They are also required to provide further documentation and evidence if the Minister of Environment Services decides to demand such information. Under the heavy regulatory compliance pressures, optimizing these batteries' "track and trace" capabilities has become a top priority within the TPL supply chain. Moreover, the TPL firm must communicate with the equipment installation company to ensure that one of their teams will be available at the dedicated remote site to take charge of the removal of old batteries, control and set-up the new batteries, and confirm the exact quantities of the batteries that are removed and installed by signing the paper-based project order.

\section{RFID implementation at the TPL firm}

The current RFID implementation focus in the TPL supply chain is shown in Figure 6. The figure also shows future extension options of the current implementation, and the optimal solutions for creating value across the supply chain from the portfolio of RFID projects.

Results from interviews, on-site observations, the three focus groups and the "Living Laboratory" facilitated data triangulation and enabled all the supply chain stakeholders to identify two plausible RFID-enabled supply chain optimization scenarios that could be implemented. In the first scenario, which is considered as the best RFID implementation scenario by the TPL firm
Furthermore, we observed from the "Living Laboratory" that the best strategy to understand the whole potential of RFID in the supply chain was to integrate RFID in the supplier's production processes of the telecommunication batteries and other internal information systems, and then to facilitate technological knowledge transfer to the rest of supply chain firms (e.g. the same RFID tag with multiple usages, real-time access to the batteries lifetime and composition). This is feasible to achieve at first by using an automated RFID printer applicator to automatically encode and print the RFID tags, and then attach them to the core component used to manufacture batteries at the very early stage of the assembly process on the production line. This enables the suppliers to use the RFID technology to improve their internal processes such as quality control, documentation, and warehousing. The technological knowledge transfer across the supply chain can be achieved later by using an RFID portal. It consists of one RFID reader, two antennas and one light stack at the shipping dock, which is integrated to the warehouse management system to achieve a real-time validation of shipment, automatic advanced shipping notice (ASN) generation, and its transmission to the focal firm. However, achieving all these benefits depended on an initial RFID investment, which the suppliers were not ready to make. One supplier manager stated: "we can see the enormous potential of RFID technology to our business, but how do we justify the costs of its adoption and how do we pass them to our customers?".

In light of the supplier reluctance for the required initial RFID investment, the second best scenario (as shown as the current RFID implementation focus in Figure 6) was chosen to be implemented and monitored in a pilot project, which was mainly driven by the TPL firm. This scenario involved the tagging of the batteries at the focal firm facilities, prior to their transfer to the remote sites, and involved the use of the TPL firm's location- 
based system to track the shipment between the focal firm, the remote sites, and the recycling facilities.

\section{Current \& future RFID implementation across the supply chain}

As the RFID project champion, the TPL firm is very IT intensive, possesses superior IT knowledge, and uses various IT systems to communicate with its business partners - both suppliers and customers. installation team" at the remote site to confirm the quantity of new batteries, and the used ones that are to be brought to the recycling plant; and finally by the receiving clerk and the put-away clerk at the recycling plant to confirm the quantity of used batteries received. Moreover, a new document specifying the type and quantity of used batteries - and even their weight - needs to be filled at the recycling plant. This information is very valuable both for the TPL firm and its customers' accounting as it enables the TPL firm's customers to determine the financial compensation from the government and the total amount to pay to the TPL firm for its services.

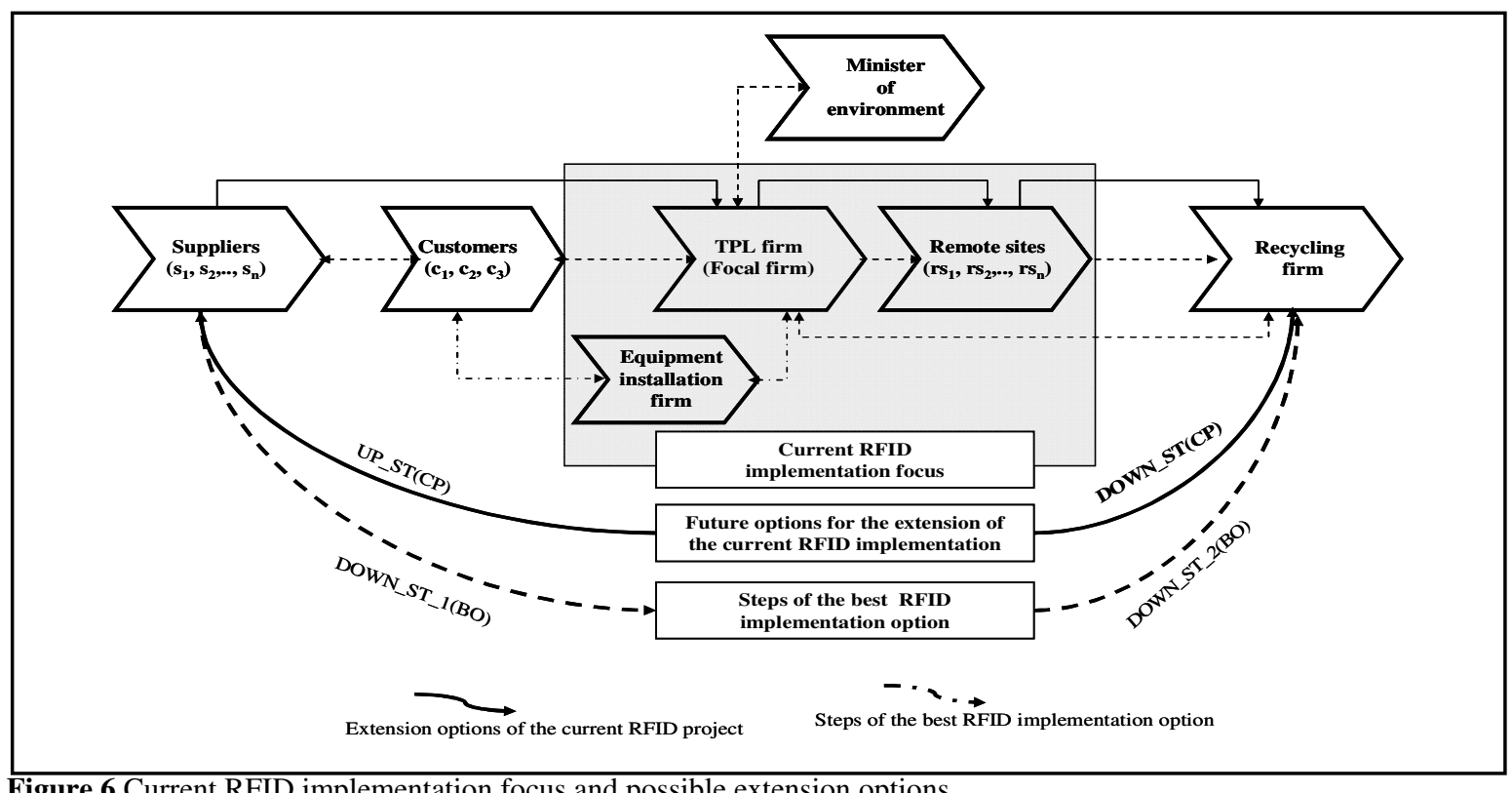

They include barcode systems to track the products, an in-house warehouse management system, a transport management system, a B2B Web portal, e-mailing, fax and Canadian postal services.

With regard to RFID, the firm has already experienced a range of RFID applications. For example, in 2005, the firm stood at the forefront of value-added services of RFID technology, and began providing a "slap \& ship" service to enable its customers to meet RFID mandates from their trading partners. Later in the same year, the TPL firm started deploying a new "Unit in Transit" system, which is an RFID-enabled truck tracking solution, as an innovative way of providing a value-added transportation service throughout North America (O'Connor, 2005). In addition, the TPL firm holds all the required authorizations and certifications in all aspects of the transport chain in Canada and the USA. In consequence, it has positioned itself as an innovator in logistics services and processes (O'Connor, 2005; RFID Solutions Online, 2007). It is in this continuum that the senior management of the TPL firm has been exploring the potential of RFID as an enabler of the supply chain management of telecommunications stationary batteries.

The current management of the telecommunication batteries requires intensive human intervention and involves a great deal of paper-based activities. For example, prior to the shipping of new batteries, the shipping clerk needs to manually prepare a "shipping manifest" to be carried by the truck driver. Then, a copy of this document needs to be signed both by the "equipment
Improving the management of these activities was, to the President of the TPL firm, the key issue to address, as he stated: "As you know, we are the only company in the Quebec province with a license to carry and dispose telecommunication batteries. Over time, our ability to offer high value services and meet our customers' requirements has created a high level of trust between us. For example, the vast majority of activities related to the management of telecommunication batteries are currently based on this trust. Currently, there is no way to justify and prove, without doubt, the quantities of used batteries transported and recycled. Having a tool that provides real-time visibility on the batteries management will not only reduce our handling costs, but will enable us to position ourselves in the whole Quebec province as a "green company" that works to respect the environment. Furthermore, if the Ministry of Environment Service can access to all required information in real-time, it will no longer have to do annual audits and send people across the supply chain to conduct checking".

\section{Execution of the pilot project}

The RFID pilot project commenced at the beginning of December 2007 and went live throughout February 2008 (Table 1). The pilot project was executed in four key phases: (1) The physical site survey and the selection and acquisition of different components of the RFID infrastructure; (2) The installation and testing of the 
different components of the RFID infrastructure and its integration with the focal firm's IT infrastructure; (3) The system testing and scenarios testing; and (4) The initial use of the RFID system to support activities related to the management of telecommunication batteries or go-live.

The RFID architecture used in the pilot project involved a SATO RFID printer that was connected to a RFID middleware called an Operation Management System (OMS). OMS middleware allows the collection, analysis and communication of automatically captured data within an RFID-enabled network system (OMS, 2009, p. 1). OMS was designed by a Canadian company, Ship2Save, to write all of the required product information, and print the required number of passive EPC Gen-2 RFID tags of each battery shipment in accordance with the information provided by the firm WMS. A Motorola mobile RFID reader was then used to read and validate the information on the RFID tags in the TPL warehouse facilities and during onsite transactions at the remote sites and recycling plant facilities. The existing TPL RFID portal consists of two RFID-Symbol antennas connected to a fixed Alien EPC Gen-2 RFID reader, which, on its part, is linked to the same OMS middleware together with their "Unit in Transit" system. These were also used during the shipping process, the automatic generation of the ASN, and the real-time update of the battery inventory in the TPL firm WMS and the tracking and tracing of the battery shipments.

Table 1 Phases undertaken during the pilot study

\begin{tabular}{|c|c|}
\hline Phases & Activities \\
\hline \multirow[t]{2}{*}{$\begin{array}{l}\text { Phase 1: Commencing } \\
\text { in early December } \\
2007\end{array}$} & $\begin{array}{l}\text { - Physical site survey in order to } \\
\text { identify potential risks in the } \\
\text { warehouse that may affect the } \\
\text { implementation and the operation } \\
\text { of the RFID infrastructure for } \\
\text { telecommunication battery } \\
\text { management }\end{array}$ \\
\hline & $\begin{array}{l}\text { - Selection and acquisition of } \\
\text { different components of the } \\
\text { current RFID infrastructure } \\
\text { through the RFID solution } \\
\text { provider involved in the pilot }\end{array}$ \\
\hline \multirow[t]{4}{*}{$\begin{array}{l}\text { Phase } 2 \text { : Commencing } \\
\text { in the middle of } \\
\text { December } 2007\end{array}$} & $\begin{array}{l}\text { 1. Installation and testing of } \\
\text { different components of the } \\
\text { current RFID infrastructure }\end{array}$ \\
\hline & $\begin{array}{l}\text { 2. Integration of the current RFID } \\
\text { infrastructure with: }\end{array}$ \\
\hline & $\begin{array}{l}\text { - Warehousing activities related } \\
\text { to managing telecommunication } \\
\text { batteries }\end{array}$ \\
\hline & $\begin{array}{l}\text { - The existing RFID } \\
\text { infrastructure, the WMS, the } \\
\text { warehouse local area network and } \\
\text { the location based system ("Unit } \\
\text { in Transit") }\end{array}$ \\
\hline $\begin{array}{l}\text { Phase } 3 \text { : Commencing } \\
\text { in early February } 2008\end{array}$ & $\begin{array}{l}\text { System and scenarios testing to } \\
\text { validate the reliability of the } \\
\text { system }\end{array}$ \\
\hline
\end{tabular}

\begin{tabular}{l}
\hline Phase 4: Commencing $\quad$ Go-live \\
at the end of February \\
2008
\end{tabular}

Through the use of the current RFID pilot project infrastructure, the TPL firm's customers can now have better visibility of all processes from the warehouse dispatch of batteries to the recycling plant in real time. Besides its new track and trace capabilities, the use of RFID technology enabled the firm to reduce paper-based activities (e.g., a paper-based project order), and also enables the automatic generation and exchange of all legally required information, such as evidence of the used batteries that were brought to the recycling plant rather than were discarded in a landfill. However, the achievement of these benefits has also introduced a set of new non-value added activities in the TPL warehouse management, such as the printing of EPC Gen-2 RFID tags and their manual application on the batteries.

\section{Discussion}

The TPL firm in our case study enables its customers to focus on their core competencies and to provide organizational flexibility in their adaptation to new technology, resources, and workforce size (Bayraktar et al., 2008). In this sense, major TPL activities have become commoditized (van Hoek, 2000). In consequence, many TPL firms are now under competitive pressure to innovate constantly in order to create value for their customers through an innovative use of IT. The environmental upheaval for the TPL firm was its leader's realization of the competitive pressure for constant innovation for survival. Hence, as our contingency model postulates, this environmental upheaval has a positive impact on facilitating the second-order organizational learning that is important for organizational transformation.

However, the TPL firm's up-stream manufacturers and suppliers of batteries were not under the same competitive pressure as the focal firm. In their case, the environmental upheaval amounted to the business need to comply the customer mandate for RFID use, which they did by printing the RFID labels and performing an add-on "slap \& ship" activity. The level of their environmental upheaval was not high enough to motivate the effective second-order organizational learning or organizational transformation that is required for them to realize higher level RFID benefits from the project.

In contrast, the Canadian TPL firm has achieved the higher RFID benefits, which match the "intra-organizational" level benefits discussed earlier in Section 3. More specifically, the TPL firm, as the result of the current RFID pilot project, has leveraged its RFID infrastructure and has eliminated all paper based activities related to the management of batteries, and therefore has also created new high-value services, such as the new track and trace capabilities of batteries and the internal real-time inventory update in its WMS during the shipping process. However, the TPL firm could not realize the higher level RFID benefits at the inter-organizational level and at the supply chain network level. In analyzing the level of organizational transformation at the supply chain level, there was no evidence of RFID-enabled radical overhaul of the inter-organizational business processes and routines within the supply chain. There was no evidence of the use of RFID as a means for designing new processes and new 
organizational architecture to optimize the supply chain level efficiency.

Furthermore, a set of interesting observations has emerged from the pilot project in relation to the applicability of our contingency model. For example, we need to carefully distinguish the level of RFID integration from the level of RFID use within the supply chain. We observed that the TPL firm was able to solve most of its managerial issues concerning the transportation of telecommunication batteries from its warehouse facilities to the remote sites, and from the remote sites to the recycling plant, with virtually no business process transformation at the remote sites and the recycling plant facilities as well as little RFID-IS integration at these two last locations,. However, even if the batteries are now equipped with RFID tags, the recycling plant and the equipment installation firm do not use them to optimize their internal operations because of the lack of organizational transformation and the low level of RFID and IS integration at these locations.

In this pilot project, all RFID implementation costs - RFID infrastructure, consulting, staff training, site survey, equipment testing and installation - were supported by the TPL firm, even though other stakeholders realized some benefits generated by the network technology. For example, the TPL firm's customers can now have access to real-time information about their battery shipment with no extra costs. Furthermore, the President of the 3PL firm was willing to:

(1) Provide supply chain stakeholders with financial and technological resources that may help them analyze and redesign their business processes prior to the adoption of RFID within their operations; and

(2) Provide management advice as to selecting and implementing the best RFID system for their business, because to him, the technology is "a tool to create value for the customer".

In other words, the focal firm within the supply chain has willingly absorbed all RFID implementation costs, while sharing some RFID benefits with its customers. These findings are contradictory to the current RFID literature on implementation strategies where suppliers usually absorb most of the costs (Spekman \& Sweeney II, 2006). However, the focal firm's funding strategy also raises strategic risk issues of 'lock-in' for the up-stream suppliers in the supply chain network. Indeed, this strategy could provide the TPL firm virtually absolute power and control of the entire enterprise supply chain system.

In regard to supplier adoption of RFID, the President of the TPL firm clearly demonstrated his strategic leadership during the process of RFID implementation and organizational transformation within his organization. In addition, he showed his willingness to champion RFID adoption at the supply chain level. This result is consistent with prior research on IT adoption (Chan \& Ngai, 2007; Zhu et al., 2006; Fichman, 2000; Iacovou et al., 1995 ) and with more recent research on RFID adoption (Ngai \& Gunasekaran, 2009; Brown \& Russel, 2007; Seymour et al., 2007; Sharma et al., 2007), which indicated that the support of the management team was a key determining factor.

To move beyond the current level of RFID implementation and electronic integration, the President of the 3PL firm is planning to leverage its RFID knowledge network to facilitate primarily first-order and, to a lesser extent, second-order organizational learning at the supply chain level. This knowledge network, which is shown in Figure 7, includes:
(1) A RFID solution provider which owns a large RFID laboratory for analysis, design and testing of custom RFID applications through the "Living Laboratory approach", and (2) A leading North-American RFID school which provides a wide range of RFID training (e.g. RFID introduction, RFID ROI, RFID business process optimization, RFID logistics, and RFIDindustry specific best practices). It also helps supplier stakeholders, based on their needs, to select the most "costeffective" RFID solution and conduct RFID research and development on the next generation of RFID applications. This enterprise inter-firm knowledge transfer strategy allows the TPL firm to access the technical and business knowledge beyond the firm boundaries and to incorporate RFID best practices which is necessary for successful implementation of the technology in view of higher level benefits.

Our contingency model in Figure 2 has shown a negative impact of the absence of resources commitment on organizational transformation, and hence the lower level RFID benefits realization from RFID supply chain projects. Indeed, recent empirical findings in the production and logistics environment showed that the lack of technical knowledge on RFID within firms (specially SMEs) is one of the major barriers to successful RFID implementation (Myerson, 2006; Huber et al., 2007; Whitaker et al. 2007).

The RFID solution providers advocate the use of the TPL's RFID-enabled warehouse for the real-life testing of RFID applications. In fact, virtually all best practices generated from these in vivo experiments are used both by the RFID School and the RFID solution provider to help potential users of RFID acquire knowledge and facilitate technology transfer through active learning processes. Moreover, RFID best practices and education on RFID technology are prerequisites to the launching of different initiatives aimed at advancing the RFID development (Erabuild, 2006, p. 5).

The literature on the Toyota Production Systems has clearly demonstrated the imperative of technological knowledge transfer across the extended enterprise supply chain networks for Toyota to realize the full potential benefits from the TPS investments (Dyer, 2000). Similarly, the RFID literature has also demonstrated that "for operations managers faced with decisions relating directly to the structure of the processes they manage, familiarity with its potential nuances can have an understandably critical impact on their views of new IT initiatives" (Bendoly et al., 2007, p. 426). During our March and April 2009 return visits, we found that the TPL firm had launched a new RFID entity to strengthen its current RFID knowledge network and better help various firms in their exploration, adoption and use of the technology.

In addition, this study highlights the importance of using (i) a pilot study to assess the impact of RFID technology (Pal et al., 2008; Lefebvre et al., 2006), and (ii) the "Living Laboratory" approach to effective organizational learning, which enables the stakeholders to assess various RFID implementation alternatives. More importantly this approach could facilitate the identification of the best location within the supply chain to establish the RFID baseline infrastructure in order to maximize future RFID investments within the supply chain. Indeed, the extension of the current RFID implementation can be carried out though various options (Figure 6). For example, going from the current RFID baseline infrastructure and expanding the project to the recycling firm ((DOWN_ST (CP) in Figure 6), and/or extending it to 
suppliers, that will now be in charge of the RFID tagging process (UP_ST (CP) in Figure 6)). In both cases, the technology-related network externality is increased but with at least one negative effect on the focal firm in the second case. Indeed, the extension of the project to suppliers makes some past RFID investments that were carried out by the focal firm obsolete (e.g. buying and configuring the RFID printer and linking it to the middleware). To avoid these issues while maintaining the same level of RFID benefits, the best option is to start building the RFID baseline infrastructure in the suppliers facilities, then move to the TPL firm ((DOWN_ST_1(BO) in Figure 6), and take charge of the implementation phase at the recycling firm (DOWN_ST_2(BO) in Figure 6)). positive relationship between the level of organizational transformation and the level of benefits realized from business process redesign. The contingency model draws on the framework and has explicated five contingency factors influencing value creation from RFID supply chain projects: environmental upheaval; leadership; second-order organizational learning; resources commitment; and organizational transformation.

Using the contingency model as a conceptual guide, we have also performed an analysis of longitudinal real-world case data from a Canadian third-party logistics service firm's seven-layer supply chain RFID projects. The case study analysis provides evidence for the imperative of the contingency factors identified in the model for creating value from the RFID projects.

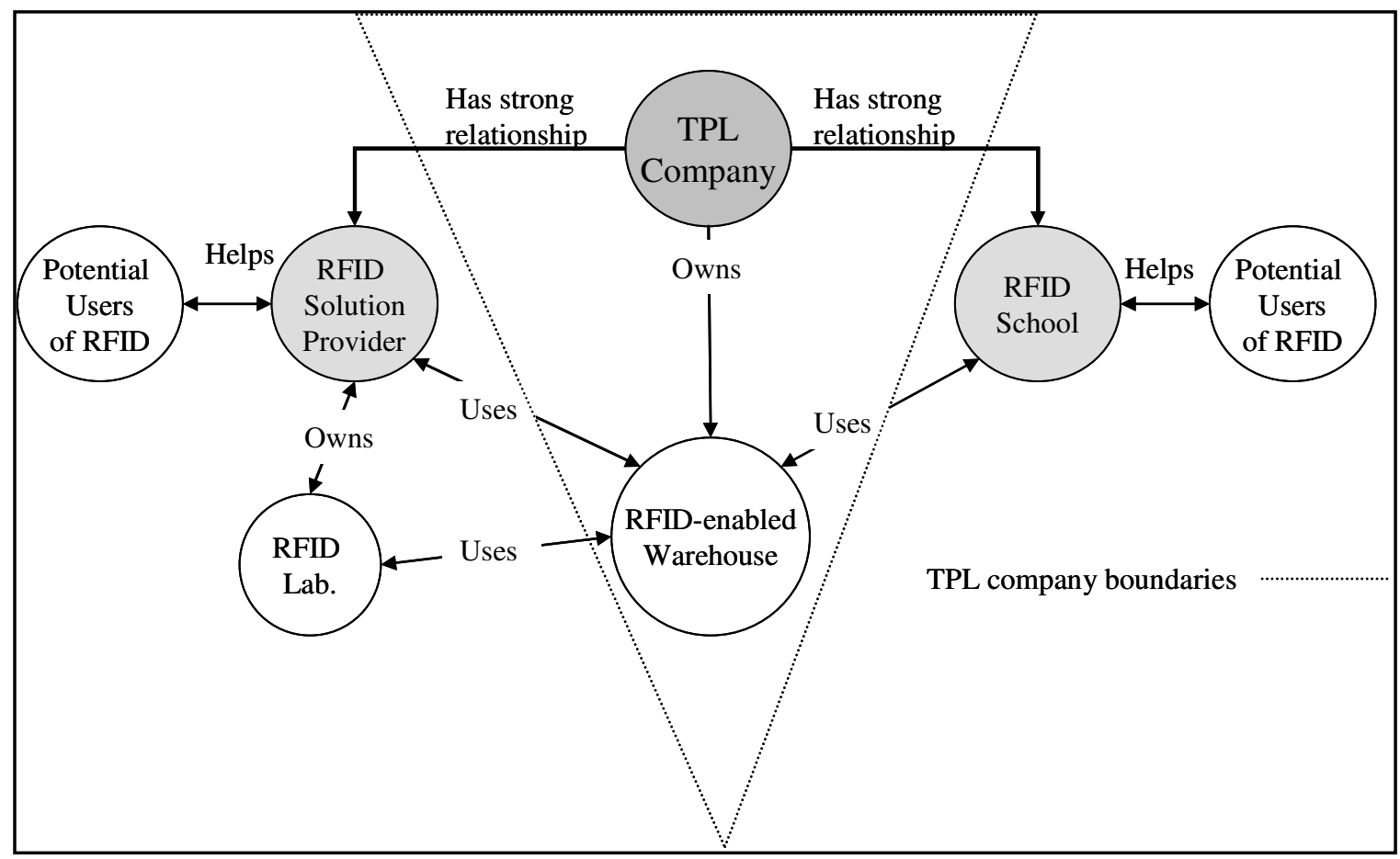

Figure 7 The TPL organizational learning capabilities: leverage on a RFID network of knowledge

\section{Conclusion}

Despite the potential of RFID technology, few RFID adopting firms have so far realized its full benefits. In the growing literature on RFID and other network technologies, the importance of organizational transformation at the supply chain level has been recognized. However, the literature lacks conceptual model development and salient mechanisms for achieving the level of organizational transformation required for stakeholders to realize the full business benefits from RFID projects. Furthermore, the RFID adoption, use, and impact studies to date, largely focus on a single firm settings and on the retail sector. Therefore, this study has attempted to fill this knowledge gap in the literature and has developed a contingency model for creating value from RFID supply chain projects in logistics and manufacturing environments.

For our model development, we draw on extant diverse literatures; particularly the framework for IT-enabled business transformation (Venkatraman, 1994) and leadership and organizational learning. The Venkatraman framework postulates a
Furthermore, it also reveals the differential costs for the focal firm and the up-stream manufacturing as a key barrier to realizing the full RFID benefits at the supply chain level.

The contingency model has managerial implications for those organizations that are motivated to realize the full RFID benefits at the supply chain level:

1. Organizational learning - particularly change-oriented secondorder organizational learning - is imperative and should be considered as the lever to achieve higher level RFID benefits across the supply chain network.

2. It is important to identify tangible and intangible costs that are associated with different levels of the expected benefits each organization wants to realize.

3. Effective leadership at the senior management level is important to channel the impact of an environmental upheaval positively to facilitate second-order organizational learning. Moreover, effective leadership is also important to ensure the commitment of resources such as sufficient financial resources and project teams, which are required to support and sustain the 
level of organizational transformation, and hence, the desired level of RFID benefits from the supply chain projects.

RFID technologies are network technologies, and disruptive technologies, with a potential great impact on current supply chain management practices. Through its focus on value creation via RFID adoption and effective use of real-time and locationbased ubiquitous data both by a TPL service provider and manufacturing firms (upstream suppliers), our model reveals the critical importance of contingency factors influencing value creation from RFID supply chain projects: environmental upheaval; leadership; second-order organizational learning; supplier resources commitment; and organizational transformation. Managerially, the contingency model provides practical knowledge to supply chain stakeholders in order for them to realize higher levels of operational and strategic benefits, which may therefore potentially transform the entire supply chain network operations.

The research reported here is bounded in two ways. First, the contingency model was not validated against an independent set of empirical data. Further research could be useful to test and validate the model using other empirical data from a real-world case study and/or a field survey of stakeholders of a supply chain network that has adopted RFID. Second, the contingency model reflects a specific context of early RFID adopters in the TPL service industry and the manufacturing industry, particularly upstream suppliers of manufacturing products involved in the logistics supply chain network. Further research might compare different industry supply chain networks with those analyzed and reported in this article.

\section{References}

ADLER P GOLDOFTAS B and LEVINE D (1999) Flexibility versus efficiency? a case study of model changeovers in the Toyota production system. Organization Science 10(1), 43-68.

ALPHA RESEARCH CONSORTIUM (2004) Characteristics, strategies and trends for 3PL/4PL in Australia. http://www.laa.asn.au/_data/page/419/3PL4PL_Report.PDF.

ARGYRIS C (1991) Teaching smart people how to learn. Harvard Business Review 69(3), 99-109.

ARGYRIS C and SCHÖN D (1978) Organizational learning: a theory of action perspective, reading, mass. Addison Wesley.

ASIF A and MANDVIWALLA M (2005) Integrating the supply chain with RFID: a technical and business Analysis. Communications of the Association for Information Systems 15, 393-427.

BARDAKI C, PRAMATARI K and DoukIDIS GI (2007) RFID-enabled supply chain collaboration services in a networked retail business environment. Bled eConference eMergence: Merging and Emerging Technologies, Processes, and Institutions, June 4-6, Bled, Slovenia.

BARRATT M (2004) Unveiling enablers and inhibitors of collaborative planning. The International Journal of Logistics Management 15(1), 73-90.

Bayraktar E, KoH SCL, Gunasekaran A, Sari K and Tatoglu E (2008) The role of forecasting on bullwhip effect for e-SCM applications. International Journal of Production Economics 113(1), 193-204

Benbasat I, Goldstein DK, Mead M (1987) The case research strategy in studies of information-systems. MIS Quarterly 11(3), 369-386.
BendaVid Y, LeFebVRe É, LeFEbVRe L.A and Fosso WAmba S (2009) Key performance indicators for the evaluation of RFID-enabled B-to-B e-commerce applications: The case of a five-layer supply chain. Information Systems and E-Business Management 7(1), 1-20.

Bendoly E, Citurs A and Konsynski B (2007) Internal infrastructural impacts on RFID perceptions and commitment: knowledge, operational procedures, and informationprocessing standards. Decision Sciences 38(3), 423-449.

Bensel P, Gunther O, Tribowski C and Vogeler S (2008) Costbenefit sharing in cross-company RFID applications: A case study approach. Twenty Ninth International Conference on Information Systems (ICIS), Paris, France, 1-17.

BergVall-Kareborn B, Hoist M and Stahlbrost A (2009) Concept design with a Living Lab approach. HICSS'09: 42nd Hawaii International Conference on System Sciences, 5-8 January, Hawaii, USA, 1-10.

BosE I and LAM CW (2008) Facing the challenges of RFID data management. International Journal of Information Systems and Supply Chain Management 1(4), 1-19.

BosE I and PAL R (2005) Auto-ID: managing anything, anywhere, anytime in the supply chain. Communications of the ACM 48(8), 100-106.

Bovenschulte M, Gabriel P, Gaßner K and Seidel U (2007) RFID: prospectives for Germany. http://www.bmwi.de/BMWi/.

BROWN I and RUSSEL J (2007) Radio frequency identification technology: An exploratory study on adoption in the South African retail sector. International Journal of Information Management 27 (4), 250-265.

CANNON AR, REYES PM, FRAZIER GV and PRATER EL (2008) RFID in the contemporary supply chain: Multiple perspectives on its benefits and risks. International Journal of Operations \& Production Management 28(5), 433-454.

CHAN SCH and NGAI EWT (2007) A qualitative study of information technology adoption: how ten organizations adopted Web-based training. Information Systems Journal 17, 289-315.

ChATFIEld A and BJøRN-ANDERSEN N (1997) The impact of IOSenabled business process change on business outcomes: transformation of the value chain of Japan airlines. Journal of Management Information Systems 14(1), 13-40.

Chatfield A and YetTon P (2000) Strategic payoff from EDI as a function of EDI embeddedness. Journal of Management Information Systems 16(4), 195-224.

CHUANG ML and SHAW WH (2007) RFID: integration stages in supply chain management. IEEE Engineering Management Review 35(2), 80-87.

Curtin J, KaufFMan RJ and Riggins FJ (2007) Making the most out of RFID technology: a research agenda for the study of the adoption, usage and impact of RFID. Information Technology and Management 8(2), 87-110.

DAVIDSON E J (2002) technology frames and framing: a sociocognitive investigation of requirements determination. MIS Quarterly 26(4), 329-358.

DUNPHY D and STACE D (1988) Transformational and coercive strategies for planned organizational change: Beyond the O.D. model. Organization Studies 9(3), 317-334.

DYER J (2000) Collaborative advantage: winning through extended enterprise supplier networks. New York: Oxford University Press. 
EISENHARDT KM (1989) Building theories from case study research. Academy of Management Review 14(4), 532-550.

ENGLUND R and BUCERO A (2006) Project sponsorship: achieving management commitment for project success. San Francisco, CA: Jossey-Bass Business \& Management.

ERABUILD (2006) Review of the current state of radio frequency identification (RFID) technology, its use and potential future use in Construction. Working paper. http://akseli.tekes.fi/opencms/opencms/OhjelmaPortaali/.

Evangelista P and SweEney E (2006) Technology usage in the supply chain: the case of small 3PLs. The International Journal of Logistics Management 17(1), 55-74.

FICHMAN RG (2000) The diffusion and assimilation of information technology innovations. In framing the domains of IT management: projecting the future through the past, Robert Zmud editor, Pinnaflex Publishing.

Fontanella J (2004) Finding the ROI in RFID. Supply Chain Management Review 8(1), 13-14.

Fosso WAMBA S and BOECK H (2008) Enhancing information flow in a retail supply chain using RFID and the EPC network: a proof-of-concept approach, Journal of Theoretical and Applied Electronic Commerce Research, Special Issue on "RFID and Supply Chain Management"3(1), 92-105.

Fosso Wamba S, Lefebvre LA, Bendavid Y and LeFebvre É (2008) Exploring the impact of RFID and the EPC network on mobile B2B ecommerce: a case study in the retail industry. International Journal of Production Economics, Special Issue on RFID: Technology, Applications, and Impact on Business Operations 112(2), 614-629.

Fosso WAMBA S, LeFEBVRE LA and LeFEBVRE É (2006) Enabling intelligent B-to-B ecommerce supply chain management using RFID and the EPC network: a case study in the retail industry. The Eighth International Conference on Electronic Commerce (ICEC), August 14-16, 2006, Fredericton, New Brunswick, Canada: 281-288.

Frohlich MT and WeStBRoOK R (2001) Arcs of integration: an international study of supply chain strategies. Journal of Operations Management 19, 185-200.

Garcia A, Chang Y Abarca A and OH C (2007) RFID enhanced MAS for warehouse management. International Journal of Logistics Research and Applications 10(2), 97-107.

Goswami S, TeO HH and Chan HC (2008) Real options from RFID adoption: The role of institutions and managerial mindfulness. International Conference on Information Systems (ICIS) Proceedings, Paris, France.

GROVER V and SAEED K (2007) The impact of product, market, and relationship characteristics on interorganizational system integration in manufacturer-supplier dyads. Journal of Management Information Systems 23(4), 185-216.

GunASEKARAN A and NGAI EWT (2004) Information systems in supply chain integration and management. European Journal of Operational Research 159, 269-295.

HALL R (1987) Attaining manufacturing excellence. Sydney: McGraw-Hill.

Hardgrave BC, Waller M and Miller R (2005) Does RFID reduce out of stocks? a preliminary analysis. Information technology research institute. http://itri.uark.edu/research/default.asp

HEESE HS (2007) Inventory record inaccuracy, double marginalization, and RFID adoption. Production and Operations Management 16(5), 542-553.
Hingley M, TAYLOR S and Ellis C (2007) Radio frequency identification tagging: Supplier attitudes to implementation in the grocery retail sector. International Journal of Retail \& Distribution Management 35(10), 803-820.

Huber N, MichaEL K and McCATHIE L (2007) Barriers to RFID adoption in the supply chain. IEEE RFID Eurasia, 1-6.

IACOVOU CL, BENBASAT I and DEXTER, AS (1995) Electronic data interchange and small organizations: Adoption and impact of technology. MIS Quarterly 19(4), 465-485.

Jones P, Clarke-Hill C, Shears P, Comfort D and Hillier D (2004) Radio frequency identification in the UK: Opportunities and challenges. International Journal of Retail \& Distribution Management 32(3), 164-71.

KÄRKKÄINEN M and HOLMSTRÖM J (2002) Wireless product identification: enabler for handling efficiency, customisation and information sharing. Supply Chain Management: An International Journal 7(4), 242-252.

Konsti-LAAKSO S, HENNALA L and UOTILA T (2008) Living Labs: new ways to enhance innovativeness in public sector services. 14th International Conference on Concurrent Enterprising, Innovation \& Living Labs, June 23-25, Lisbon, Portugal.

KOTTER J (2007) Leading change why transformation efforts fail. Harvard Business Review 85(1), 96-103.

KOTTER J and SCHLESINGER L (2008) Choosing strategies for change. Harvard Business Review 86(7/8), 130-139.

KRAEMER KL, DEDRICK J, MELVILLE N and ZHU K (2006) Global e-commerce: Impacts of national environments and policy. Cambridge University Press, Cambridge, U.K., 466 p.

KUSIAK, A (2007) Innovation: the living laboratory perspective. Computer-Aided Design \& Applications 4(6), 863-876.

LAI KH, WONG CWY and CHENG TCE (2006) Institutional isomorphism and the adoption of information technology for supply chain management. Computers in Industry 57, 93-98.

LAI K, WONG C and CHENG T (2008) A coordination-theoretic investigation of the impact of electronic integration on logistics performance. Information \& Management 45(1), 1020.

LAMBERT DM and COOPER MC (2000) Issues in supply chain management. Industrial Marketing Management 29, 65-83.

LANT T AND MEZIAS S (1992) An organizational learning model of convergence and reorientation. Organization Science 3(1), $47-$ 71.

LEE CP and SHIM JP (2007) An exploratory study of radio frequency identification (RFID) adoption in the healthcare industry. European Journal of Information Systems 16, 712 724.

LEE D and PARK J (2008) RFID-based traceability in the supply chain. Industrial Management \& Data Systems 108(6), 713725 .

LeFebvre LA, Lefebvre É, Bendavid Y, Fosso Wamba S and BOECK H (2006) RFID as an enabler of B-to-B e-Commerce and its impact on business processes: a pilot study of a supply chain in the retail industry. 39th Hawaii International Conference on Systems Science (HICSS-39), January 4-7, 2006 Kauai, Hawaii.

LEGNER C and SCHEMM J (2008) Toward the inter-organizational product information supply chain - evidence from the retail and consumer goods industries. Journal of the Association for Information Systems 9(3/4), 119-150.

LEIMEISTER S, LEIMEISTER JM, KNEBEL U, AND KRCMAR H (2009) A cross-national comparison of perceived strategic importance 
of RFID for CIOs in Germany and Italy. International Journal of Information Management 29(1), 37-47.

LOEBBECKE C (2007) Piloting RFID along the supply chain: a case analysis. Electronic Markets 17(1), 29-38.

LOEBBECKE C and HuYSKENS C (2008) Item-level RFID in the Japanese publishing industry: a case study. The Communications of the Association for Information Systems (CAIS), (in press).

LOEBBECKE C and PALMER J (2006) RFID in the fashion industry: Kaufhof department stores AG and Gerry Weber International AG, Fashion Manufacturer. Management Information Systems Quarterly Executive (MISQE) 5(2), 15-25.

LoeH H. (2005) Concurrent product development and new communication technologies: a research framework. Working Paper CeTIM, /http://www.cetim.org/wps/

MARASCO A (2008) Third-party logistics: a literature review. International Journal of Production Economics 113(1), 127147.

Michael K and McCATHIE L (2005) The pros and cons of RFID in supply chain management. Proceedings of the International Conference on Mobile Business, 11-13 July 2005, Sydney Australia 623-629.

MOON KL and NGAI EWT (2008) The adoption of RFID in fashion retailing: a business value-added framework. Industrial Management \& Data Systems 108(5), 596-612.

MuRPHY PR and POIST RF (1998) Third-party logistics usage: an assessment of propositions based on previous research. Transportation Journal 37(4), 26-35.

MyERSON JM (2006) RFID in the Supply Chain: a Guide to Selection and Implementation. Business \& Economics.

NÄSLUND D (2002) Logistics needs qualitative research especially action research. International Journal of Physical Distribution \& Logistics Management 32(5), 321-338.

NEWMAN K (2000) Organizational transformation during institutional upheaval. Academy of Management Review 25(3), 602-619.

NGai EWT \& GunaseKaran, A. (2009). RFID adoption: Issues and challenges. International journal of enterprise information systems 5(1), 1-8.

Ngai EWT, Moon KKL, Riggins FJ and Yi CY (2008a) RFID research: an academic literature review (1995-2005) and future research directions. International Journal of Production Economics 112(2), 510-520.

Ngai EWT, Cheng TCE, Au S and LAI KH (2007) Mobile commerce integrated with RFID technology in a container depot. Decision Support Systems 43(1), 62-76.

NGAI EWT, SUK FFC and Lo SYY (2008b) Development of an RFID-based sushi management system: the case of a conveyor-belt sushi restaurant. International Journal of Production Economics 112(2), 630-645.

O'CONNOR MC (2005) Canadian freight courier rolls out RFID: Liaison Can/U.S. is using active and passive RFID tags to help it keep better tabs on the goods it transports. RFID Journal, http://www.rfidjournal.com/article/view/1764/1/1

OMS (2009) OMS. http://www.ship2save.com/.

ORLIKOWSKI W (1993) CASE tools as organizational change: Investigating incremental and radical changes in systems development. MIT WP \#3579-93, May 1993.

Pal R, SEngupta A and Bose I (2008) Role of pilot study in assessing viability of new technology projects: the case of
RFID in parking operations. Communications of the Association for Information Systems 23, 257-276.

POIRIER CC (2002) Achieving supply chain connectivity. Supply Chain Management Review 6, 16-21.

Power D, Sharafali M and BhaKoo V (2007) Adding value through outsourcing contribution of 3PL services to customer performance. Management Research News 30(3), 228-235.

Prater E, Frazier GV and ReYES PM (2005) Future impacts of RFID on e-supply chains in grocery retailing. Supply Chain Management: An International Journal 10(2), 134-142.

Ragatz GL, HandField RB and SCANNELl TV (1997) Success factors for integrating suppliers into new product development. Journal of Product Innovation Management 14, 190-202.

RAZZAQUE MA and SHENG CC (1998) Outsourcing of logistics functions: a literature survey. International Journal of Physical Distribution \& Logistics Management 28(2), 89-107.

RFID SOLUTIONS ONLINE (2007) Using RFID technology to derive business value. http://www.rfidsolutionsonline.com/.

RoBEy D, IM G and WAREHAM JD (2008) Theoretical foundations of empirical research on interorganizational systems: Assessing past contributions and guiding future directions. Journal of the Association for Information Systems (JAIS) 9(9), 497-518.

Rogers EM (1995) Diffusion of innovations. Free Press, New York.

SABbaghi A and VaidyanAthan G (2008) Effectiveness and efficiency of RFID technology in supply chain management: strategic values and challenges. JTAER 3(2), 71-81.

SABBAGHI A and VAIDYANATHAN G (2007) Efficiency of RFID in supply chain management: strategic benefits and challenges. Issues in Information Systems 8(2), 443-448.

SCHEIN E (2004) Organizational Culture and Leadership. Third edition, San Francisco, CA: Jossey-Bass.

SCHMitT P and MichahElles F (2009). Status of RFID/EPC adoption. Auto-ID Labs White paper WP-BIZAPP-048, March 2009.

SEYMOUR L, EMMA LP and WILLUWEIT L (2007) RFID adoption into the container supply chain: Proposing a framework. Proceedings of the 6th Annual ISOnEworld Conference, Las Vegas, USA.

SHARMA A, CITURS A and KONSYNSKI B (2007) Strategic and institutional perspectives in the adoption and early integration of radio frequency identification (RFID). Proceedings of the 40th Hawaii International Conference on System Sciences, IEEE Computer Society, January 5-8, Hawaii, USA.

SPEKMAN RE and SwEENEY II PJ (2006) RFID: from concept to implementation. International Journal of Physical Distribution \& Logistics Management 36(10), 736-754.

SRIVASTAVA B (2004) Radio frequency ID technology: the next revolution in SCM. Business Horizons 47(6), 60-68.

StroH S and Ringbeck J (2004) Thinking outside the closed loop. Strategy+business Magazine, April, 1-4.

TEO TSH and PIAN Y (2003) A contingency perspective on Internet adoption and competitive advantage. European Journal of Information Systems 12, 78-92.

TEO HH, WEI KK and BENBASAT I (2003) Predicting intention to adopt interorganizational linkages: An institutional perspective. MIS Quaterly 27 (1), 19-50.

TORNATZKY LG and KLEIN KJ (1982) Innovation characteristics and innovation adoption and implementation: a meta analysis 
of findings. IEEE Transactions on Engineering Management 29(11), 28-45.

Tushman $M$ and ANDERson $P$ (1986) Technological discontinuities and organizational environments. Administrative Science Quarterly 31(3), 439-465.

VAIL PJ and AGARWAL N (2007) Disruptive innovation offers farreaching solutions. Potentials, IEEE 26 (2), 25-33.

VAN DE VEN A AND PoOLE M (1995) Explaining development and change in organizations. Academy of Management Review 20(3), 510-540.

VAN HOEK IR (2000) The purchasing and control of supplementary third-party logistics services. Journal of Supply Chain Management 36(4), 14-26.
WhitAKER J, Mithas S and KrishnAN M (2007) A field study of RFID deployment and return expectations. Production and Operations Management 16(5), 599-612.

White A, Johnson M and WiLson H (2008) RFID in the supply chain: Lessons from European early adopters. International Journal of Physical Distribution \& Logistics Management 38(2), 88-107.

YIN RK (1994) Case study research: Design and methods. Newbury Park, CA: Sage, 192 p.

Zhu K, Dong S, Xu SX and Kraemer K L (2006) Innovation diffusion in global contexts: Determinants of post-adoption digital transformation of European companies. European Journal of Information Systems (15), 601-616.

VENKATRAMAN N (1994) IT-enabled business transformation: from automation to business scope redefinition. Sloan Management Review 35(2), 73-87. 